Article

\title{
Fatty Acid-Binding Proteins Aggravate Cerebral Ischemia-Reperfusion Injury in Mice
}

\author{
Qingyun Guo $^{1}{ }^{\circledR}$, Ichiro Kawahata ${ }^{1}{ }^{\circledR}$, Tomohide Degawa ${ }^{1}$, Yuri Ikeda-Matsuo ${ }^{2}{ }^{\oplus}$, Meiling Sun ${ }^{1}$, Feng $\operatorname{Han}^{3}$ \\ and Kohji Fukunaga ${ }^{1, *(1)}$
}

1 Department of Pharmacology, Graduate School of Pharmaceutical Sciences, Tohoku University, 6-3 Aramaki-Aoba, Aoba-Ku, Sendai 980-8578, Japan; guo.qingyun.r2@dc.tohoku.ac.jp (Q.G.); kawahata@tohoku.ac.jp (I.K.); tomohide.degawa.r2@dc.tohoku.ac.jp (T.D.); reiko.fukunaga.e2@tohoku.ac.jp (M.S.)

2 Laboratory of Pharmacology, Department of Clinical Pharmacy, Faculty of Pharmaceutical Sciences, Hokuriku University, Kanagawa-Machi, Kanazawa 920-1181, Japan; y-matsuo@hokuriku-u.ac.jp

3 School of Pharmacy, Nanjing Medical School, Nanjing 211166, China; fenghan169@njmu.edu.cn

* Correspondence: kfukunaga@tohoku.ac.jp; Tel.: +81-22-795-6836

Citation: Guo, Q.; Kawahata, I.; Degawa, T.; Ikeda-Matsuo, Y.; Sun, M.; Han, F.; Fukunaga, K. Fatty Acid-Binding Proteins Aggravate Cerebral Ischemia-Reperfusion Injury in Mice. Biomedicines 2021, 9, 529 . https://doi.org/10.3390/ biomedicines 9050529

Academic Editor: Kumar Vaibhav

Received: 20 March 2021

Accepted: 4 May 2021

Published: 10 May 2021

Publisher's Note: MDPI stays neutral with regard to jurisdictional claims in published maps and institutional affiliations.

Copyright: (c) 2021 by the authors. Licensee MDPI, Basel, Switzerland. This article is an open access article distributed under the terms and conditions of the Creative Commons Attribution (CC BY) license (https:// creativecommons.org/licenses/by/ $4.0 /)$.

\begin{abstract}
Fatty acid-binding proteins (FABPs) regulate the intracellular dynamics of fatty acids, mediate lipid metabolism and participate in signaling processes. However, the therapeutic efficacy of targeting FABPs as novel therapeutic targets for cerebral ischemia is not well established. Previously, we synthesized a novel FABP inhibitor, i.e., FABP ligand 6 [4-(2-(5-(2-chlorophenyl)-1(4-isopropylphenyl)-1H-pyrazol-3-yl)-4-fluorophenoxy)butanoic acid] (referred to here as MF6). In this study, we analyzed the ability of MF6 to ameliorate transient middle cerebral artery occlusion (tMCAO) and reperfusion-induced injury in mice. A single MF6 administration $(3.0 \mathrm{mg} / \mathrm{kg}$, per os) at $0.5 \mathrm{~h}$ post-reperfusion effectively reduced brain infarct volumes and neurological deficits. The protein-expression levels of FABP3, FABP5 and FABP7 in the brain gradually increased after tMCAO. Importantly, MF6 significantly suppressed infarct volumes and the elevation of FABP-expression levels at $12 \mathrm{~h}$ post-reperfusion. MF6 also inhibited the promotor activity of FABP5 in human neuroblastoma cells (SH-SY5Y). These data suggest that FABPs elevated infarct volumes after ischemic stroke and that inhibiting FABPs ameliorated the ischemic injury. Moreover, MF6 suppressed the inflammation-associated prostaglandin $\mathrm{E}_{2}$ levels through microsomal prostaglandin E synthase-1 expression in the ischemic hemispheres. Taken together, the results imply that the FABP inhibitor MF6 can potentially serve as a neuroprotective therapeutic for ischemic stroke.
\end{abstract}

Keywords: ischemia; FABP3; FABP5; FABP7; mPGES-1; PGE 2

\section{Introduction}

Ischemic stroke is the most common cerebrovascular disease, accounting for approximately $80 \%$ of all strokes and causing a large number of deaths and disabilities worldwide [1,2]. Ischemic stroke is caused by the blockage of the artery supplying blood to the brain, and an insufficient blood supply triggers a series of complex neurochemical responses including excitotoxicity, oxidative stress and inflammation, which ultimately leads to the death and dysfunction of brain cells [3-5]. Even though the administration of intravenous thrombolysis with recombinant tissue plasminogen activator is the only clinically approved drug therapy that can effectively treat ischemic stroke, a short therapeutic window and intracerebral hemorrhagic complications limit its availability [5]. Therefore, alternative neuroprotective drugs are still required for treating acute-phase cerebral ischemia.

Fatty acid-binding proteins (FABPs) are expressed in various tissues in a highly specific manner, where they regulate fatty acid uptake, transport and metabolism [6], and play vital roles in the pathogenesis of many common diseases [7]. Most mammals produce 12 distinct 
subtypes of FABPs, although humans produce up to 10 [8], three of which are expressed in the brain, including FABP3 (heart-type), FABP5 (epidermal-type) and FABP7 (braintype) $[9,10]$. These three FABPs are expressed at specific stages during brain development. For example, FABP3 is not expressed during embryonic period and its expression gradually increases in rodent brains after birth, whereas FABP5 and FABP7 show an opposite pattern and decrease postnatally in rodents [9]. FABP homeostasis is critical for normal brain development and functions at different stages, and FABP imbalances can cause various neurodegenerative and neuropsychiatric disorders. FABP5 and FABP7 mRNA levels were higher in the cortexes of postmortem brains from schizophrenic patients than in those from healthy controls, and similar results were found for FABP7 mRNA in postmortem brains from patients with autism spectrum disorder [9]. Higher FABP3 levels have been observed in the cerebrospinal fluid and serum of patients with Alzheimer's disease, dementia with Lewy bodies or Parkinson's disease [11,12]. FABP3 deficiency prevents nicotineinduced preference behavior $[13,14]$. The FABP3 deficiency also completely abolished the induction of Parkinson's syndrome after 1-methyl-4-phenyl-1,2,3,6-tetrahydropiridine (MPTP) treatment in mice [15].

Developing specific ligands for each FABP is essential for studying the mechanisms of FABPs in neurological diseases. For example, the FABP4 ligand BMS309403 has been used as a potent and selective biphenyl azole inhibitor to improve ischemia/reperfusion (I/R) injury of the brain [16] and kidneys [17] in mice. Recently, we have developed a series of FABP3 ligands, based on BMS309403 [18]. Among these ligands, we confirmed that MF1 [19] and MF8 [20] could target FABP3 and improve motor deficits and cognitive impairments in a mouse model of MPTP-induced Parkinson's disease. Therefore, we hypothesized that FABP ligands also have neuroprotective effects to rescue neurons from ischemic injury.

In this study, we used a newly synthesized ligand 6 [4-(2-(5-(2-chlorophenyl)-1-(4isopropylphenyl)-1H-pyrazol-3-yl)-4-fluorophenoxy)butanoic acid] (named here as MF6), which has a high affinity for FABP7 (dissociation constant [Kd] value: $20 \pm 9 \mathrm{nM}$ ) [21] and has a much weaker affinity for FABP3 (Kd value: $1038 \pm 155 \mathrm{nM}$ ) and FABP5 (Kd value: $874 \pm 66 \mathrm{nM}$ ) [22,23], to examine its therapeutic effects on ischemic stroke. We defined the elevation of FABP3, FABP5 and FABP7 expression after I/R injury in mice brain and the neuroprotective effects of FABP inhibitor MF6. Our results provided a new target protein for ischemic stroke therapeutics and demonstrated the potential of FABP ligands as neuroprotective therapeutic drugs.

\section{Materials and Methods}

\subsection{Animals}

Male ICR mice (Institute of Cancer Research (ICR) mice, Slc:ICR) (5 weeks old, 25-30 g) were purchased from Japan SLC, Inc. (Shizuoka, Japan). The animals were housed under conditions of constant temperature and humidity, kept on a 12-h light-dark cycle (lights on: 09:00-21:00) and fed ad libitum. All procedures for handling animals complied with the Guide for Care and Use of Laboratory Animals and were approved by the Experimentation Committee of Tohoku University Graduate School of Pharmaceutical Sciences [2019PhLM0021 (approved date: 1 December 2019) and 2019PhA-024 (approved date: 1 April 2019)].

\subsection{Surgical Procedures Used for Establishing Transmit Middle Cerebral Artery Occlusion (Tmcao) and Reperfusion}

Mice were randomly assigned to tMCAO and sham groups. The mouse model of tMCAO was generated as previously described [24]. Briefly, adult male ICR mice were anesthetized via intraperitoneal injection with a combination of $0.3 \mathrm{mg} / \mathrm{kg}$ body weight medetomidine (Domitol, Meiji Seika Pharma Co., Ltd., Tokyo, Japan), $4.0 \mathrm{mg} / \mathrm{kg}$ midazolam (Dormicum, Astellas Pharma Inc., Tokyo, Japan) and $5.0 \mathrm{mg} / \mathrm{kg}$ butorphanol (Vetorphale, Meiji Seika Pharma Co., Ltd.). Following this, tMCAO surgical procedure was performed as follows: a silicone-coated 6-0 suture (602356PK10, Doccol Corporation, 
Sharon, MA, USA) was inserted from the right external carotid artery to the internal carotid artery, extending to the origin of a middle cerebral artery, for $2 \mathrm{~h}$. After $2 \mathrm{~h}$, the suture was removed, allowing reperfusion to occur. Mice in the sham-operation group underwent the same procedure, except for the suture insertion. Following reperfusion, mice were sacrificed at the indicated time. A homoeothermic heating blanket was used to the maintain core body temperature in each mouse at $37{ }^{\circ} \mathrm{C}$ during the I/R operation. Regional cerebral blood flow (rCBF) was monitored by laser-doppler flowmetry (FLOC1, OMEGAWAVE, Tokyo, Japan) to confirm whether the right hemisphere was in an ischemic state. When CBF was reduced by approximately $70-90 \%$, the surgery was considered successful as previously described [25].

\subsection{Drug Treatment}

MF6 (FABP ligand 6) was synthesized from BMS309403 [23], and its chemical structure is shown in Figure 1A. MF6 was suspended in 0.5\% carboxymethyl cellulose (CMC; Wako, Osaka, Japan) and administered per os (p.o.) at different doses $(0.5,1$ or $3 \mathrm{mg} / \mathrm{kg})$ just before the experiments were initiated, according to the experimental schedule described in Figure 1B-E. The corresponding control group was orally administered an equivalent volume of $0.5 \% \mathrm{CMC}$.

\subsection{Infarct Volume Evaluation}

After $24 \mathrm{~h}$ of reperfusion, the mice were decapitated, and their brains were rapidly removed and cooled to $-30{ }^{\circ} \mathrm{C}$ for $10 \mathrm{~min}$. The brains were sliced into five sections (2-mm thick), incubated in 1\% 2,3,5-triphenyltetrazolium chloride (TTC; Wako, Osaka, Japan) for $20 \mathrm{~min}$ at $37^{\circ} \mathrm{C}$ and then soaked overnight in $4 \%$ paraformaldehyde (PFA; Wako, Osaka, Japan). The infarcted areas appeared white, whereas the non-infarcted regions appeared red. Infarct volumes were measured using ImageJ software and were expressed as a percentage of the total hemisphere [24].

\subsection{Neurological Score}

Neurological function impairment was also evaluated after $24 \mathrm{~h}$ of reperfusion using a neurological deficit grading system with a scale ranging from 0 to 4 , as described previously [24]. The following scale was used as a rating system: 0, normal motor function; 1 , forelimb flexion when lifted by the tail; 2 , circling to the contralateral side when held by the tail on a flat surface, but a normal posture at rest; 3 , spontaneous leaning towards to the contralateral side when moving freely; 4 , no spontaneous motor activity with an apparent reduction in consciousness. The mice in the sham group exhibited no manifestations of neurological deficits.

\subsection{Western Blot Analysis}

Following decapitation, a second coronal slice was dissected at $12 \mathrm{~h}$ after reperfusion, and regions of the right hemisphere (the ischemic side, ipsilateral) and left hemisphere (the contralateral side) were selected and stored at $-80{ }^{\circ} \mathrm{C}$ Frozen samples were homogenized in lysis buffer (50 mM Tris- $\mathrm{HCl}, \mathrm{pH} 7.4,0.5 \%$ Triton X-100, 4 mM EGTA, $10 \mathrm{mM}$ EDTA, $1 \mathrm{mM} \mathrm{Na}_{3} \mathrm{VO}_{4}, 40 \mathrm{mM} \mathrm{Na} 2 \mathrm{P}_{2} \mathrm{O}_{7} \cdot 10 \mathrm{H}_{2} \mathrm{O}, 50 \mathrm{mM} \mathrm{NaF}, 100 \mathrm{nM}$ calyculin A, $50 \mu \mathrm{g} / \mathrm{mL}$ leupeptin, $25 \mu \mathrm{g} / \mathrm{mL}$ pepstatin $\mathrm{A}, 50 \mu \mathrm{g} / \mathrm{mL}$ trypsin inhibitor and $1 \mathrm{mM}$ dithiothreitol). The samples were then centrifuged at $12,000 \mathrm{rpm}$ for $10 \mathrm{~min}$ at $4^{\circ} \mathrm{C}$ to remove insoluble material. Protein concentrations were determined using Bradford's assay, and samples were boiled for $3 \mathrm{~min}$ at $100{ }^{\circ} \mathrm{C}$ with $6 \times$ Laemmli's sample buffer [26].

For electrophoresis, equal amounts of proteins were loaded on $15 \%$ sodium dodecyl sulfate-polyacrylamide gels and transferred to a polyvinylidene difluoride membrane for $2 \mathrm{~h}$. After blocking with T-TBS solution (50 mM Tris- $\mathrm{HCl}, \mathrm{pH} 7.5,150 \mathrm{mM} \mathrm{NaCl}$ and $0.1 \%$ Tween 20) containing 5\% fat-free milk powder for $1 \mathrm{~h}$ at room temperature, the membranes were incubated overnight at $4{ }^{\circ} \mathrm{C}$ with primary antibodies against the proteins of interest. The following working dilutions were used for the indicated monoclonal antibodies, per 
manufacturer's suggestions: mouse anti-FABP3 (1:1000; Hycult Biotech, HM2016, Uden, NLD), goat anti-FABP5 (1:1000; R\&D Systems, AF3077, Minneapolis, MN, USA), goat anti-FABP7 (1:1000; R\&D Systems, AF3166, Minneapolis, MN, USA), rabbit anti-mPGES-1 (1:200; Cayman Chemical, 160140, Ann Arbor, MI, USA) and mouse anti- $\beta$-actin (1:5000; Sigma, A5441, St Louis, MO, USA). After washing, membranes were incubated with appropriate secondary antibodies diluted in T-TBS solution for $2 \mathrm{~h}$, at room temperature. The membranes were developed using an enhanced chemiluminescence immunoblotting detection system (Amersham Biosciences, NJ, USA) and visualized with a Luminescent Image Analyzer (LAS-4000 mini, Fuji Film, Tokyo, Japan). The densities of the bands were analyzed with ImageJ software (NIH, Bethesda, MA, USA).
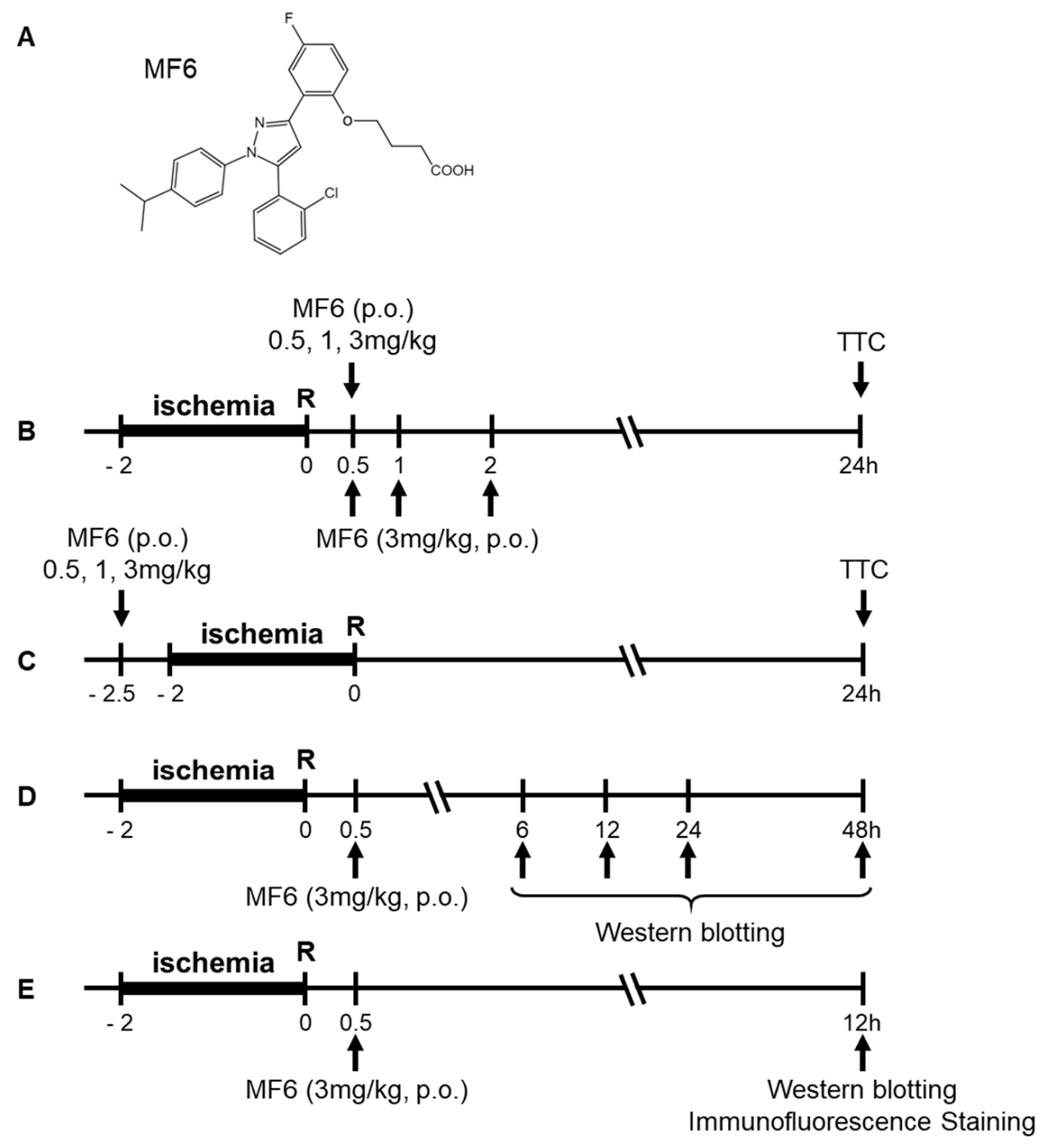

Figure 1. Experimental schedule for MF6 administration (0.5, 1 or $3 \mathrm{mg} / \mathrm{kg}$, p.o.) in $\mathrm{I} / \mathrm{R}$ mice. (A) Chemical structure of MF6. (B) ICR mice were subjected to tMCAO for $2 \mathrm{~h}$. Subsequently, they were administered orally (p.o.) different concentrations of MF6 $(0.5,1 \mathrm{or} 3 \mathrm{mg} / \mathrm{kg}) 30 \mathrm{~min}$ after reperfusion (for dose-response experiments) or $3 \mathrm{mg} / \mathrm{kg}$ MF6 at 0.5, 1 and $2 \mathrm{~h}$ after reperfusion (for time-response experiments). TTC staining was performed at $24 \mathrm{~h}$ after reperfusion. (C) MF6 (0.5, 1 or $3 \mathrm{mg} / \mathrm{kg}$ ) was administered p.o. to mice $30 \mathrm{~min}$ before reperfusion to study the effects of pretreatment. (D) MF6 (3 mg/ $\mathrm{kg}$ ) was administered to mice $30 \mathrm{~min}$ after reperfusion, and FABP levels were measured after 6, 12, 24 and $48 \mathrm{~h}$. (E) I/R mice were administered MF6 ( $3 \mathrm{mg} / \mathrm{kg}) 30 \mathrm{~min}$ after reperfusion, and after $12 \mathrm{~h}$, the brains were collected for Western blot and immunostaining analyses. 


\subsection{Immunofluorescence Staining}

Mice were anesthetized and transcardially perfused $12 \mathrm{~h}$ after reperfusion with icecold phosphate-buffered saline (PBS) immediately followed by $4 \%$ PFA, as previously described. Mouse brains were removed and fixed in $4 \%$ PFA overnight at $4{ }^{\circ} \mathrm{C}$ The brain samples were cut into $50 \mu \mathrm{m}$ coronal sections using a vibratome (Dosaka EM Co. Ltd., Kyoto, Japan). Sections were washed in PBS for $30 \mathrm{~min}$, permeabilized in PBS with $0.1 \%$ Triton X-100 for $2 \mathrm{~h}$ and blocked in PBS containing 1\% BSA and 0.3\% Triton X-100 for $1 \mathrm{~h}$ at room temperature [26]. The brain samples were then incubated with the following primary antibodies in blocking solution for $3 \mathrm{~d}$ at $4{ }^{\circ} \mathrm{C}$ : mouse anti-FABP3 (1:500), goat anti-FABP5 (1:500), goat anti-FABP7 (1:500), rabbit anti-mPGES-1 (1:200) and antibodies against cellular markers (1:500). After washing with PBS, the brain sections were incubated with Alexa Flour-conjugated secondary antibodies overnight at $4{ }^{\circ} \mathrm{C}$. After sufficient washing with PBS, the brain sections were mounted on slides with Vectashield (Vector Laboratories, Inc., Burlingame, CA, USA). Immunofluorescent images were analyzed using a confocal laser scanning microscope (Nikon, Tokyo, Japan).

\subsection{Measuring MF6 Concentrations in the Blood and Brain}

MF6 (3 mg/kg, p.o.) was administered to the mice directly (sham group) or $30 \mathrm{~min}$ after reperfusion (I/R group). Blood was collected from the tail vein for measurement at specific time intervals after injection. At 1, 4 and $48 \mathrm{~h}$ after injection, the mice were anesthetized and perfused with ice-cold PBS to remove blood to obtain brain samples, which were stored at $-80^{\circ} \mathrm{C}$ until use. The blood in heparinized tubes was centrifuged at $16,500 \times \mathrm{g}$ for $10 \mathrm{~min}$ at $4{ }^{\circ} \mathrm{C}$, after which the supernatants were collected as plasma. Plasma samples $(10 \mu \mathrm{L})$ were deproteinized by adding $250 \mu \mathrm{L}$ of acetonitrile containing ligand 2 $(2 \mathrm{ng} / \mathrm{mL})$ as an internal standard, followed by vortexing and sonication. The samples were centrifuged at $16,500 \times \mathrm{g}$ for $10 \mathrm{~min}$ at $4{ }^{\circ} \mathrm{C}$. After centrifugation, the supernatants were evaporated to dryness with a centrifugal concentrator (CC-105, TOMY, Tokyo, Japan), and then the residues were dissolved in $20 \mu \mathrm{L} 80 \%$ acetonitrile. For brain sample preparations, $1 \mathrm{~mL}$ of acetonitrile was added to $1.5 \mathrm{~mL}$ tubes containing brain hemisphere sections, after which the mixtures were homogenized with an ultrasonic homogenizer (SONIFIER Model: 250-Advanced, Branson, CT, USA) for $1 \mathrm{~min}$. Then, the samples were centrifuged at $16,500 \times g$ for $10 \mathrm{~min}$ at $4{ }^{\circ} \mathrm{C}$. Ten micro-liters of each supernatant were processed following the same procedure used for the plasma samples.

Ultra-performance liquid chromatography (UPLC; Ultimate 3000, Dionex) was performed with an ACQUITY UPLC®BEH C18 column $(2.150 \mathrm{~mm}, 1.7 \mu \mathrm{m}$, Waters, Milford, MA, USA) maintained at $40{ }^{\circ} \mathrm{C}$, with a flow rate of $400 \mu \mathrm{L} / \mathrm{min}(0-1.0 \mathrm{~min}, 2.0-3.0 \mathrm{~min})$ or $600 \mu \mathrm{L} / \mathrm{min}$ (1.0-2.0 min). Mobile phase A was composed of water containing $0.1 \%$ formic acid, and mobile phase B was composed of acetonitrile containing $0.1 \%$ formic acid. The following gradient program was used: $0-1.0 \mathrm{~min}, 80 \% \mathrm{~B} ; 1.0-2.0 \mathrm{~min}, 98 \% \mathrm{~B} ; 2.0-3.0 \mathrm{~min}$, $80 \%$ B. An injection volume of $1 \mu \mathrm{L}$ was used for analysis.

Mass spectrometry (MS) was performed using a TSQ Vantage mass spectrometer (Thermo Fisher Scientific, Waltham, MA, USA) with an electrospray ionization inter-face. Quantitative analysis was performed in selected-reaction monitoring mode (ligand 6; m/z $[\mathrm{M}+\mathrm{H}]^{+} 493.2>407.2$, ligand 2; $\left.\mathrm{m} / \mathrm{z}[\mathrm{M}+\mathrm{H}]^{+} 479.1>393.1\right)$.

\subsection{Measuring Brain PGE 2 Concentrations by Performing Enzyme-Linked Immunosorbent Assays (ELISAs)}

Prostaglandin $\mathrm{E}_{2}\left(\mathrm{PGE}_{2}\right)$ concentrations in the ipsilateral and contralateral hemispheres (Figure 4A) were determined using a Prostaglandin $E_{2}$ ELISA Kit (Cayman Chemical, 514010, Ann Arbor, MI, USA). Samples were collected into liquid nitrogen as described above and weighed. Fifty microliters homogenization buffer $(0.1 \mathrm{M}$ phosphate, $\mathrm{pH}$ 7.4, containing $1 \mathrm{mM}$ EDTA and $10 \mu \mathrm{M}$ indomethacin) was added to $1 \mathrm{mg}$ of each tissue, the samples were homogenized and centrifugated at $10,000 \times \mathrm{g}$ for $15 \mathrm{~min}$ at $4{ }^{\circ} \mathrm{C}$, 
and then $\mathrm{PGE}_{2}$ was extracted from the supernatant and quantitated according to the manufacturer's protocol.

\subsection{Cell Culture and Luciferase Reporter Assay}

Human neuroblastoma cells (SH-SY5Y) were grown in Dulbecco's modified Eagle's medium (DMEM, Wako) supplemented with $15 \%$ fetal bovine serum (FBS, Gibco, CA, USA) and $1 \%$ penicillin-streptomycin at $37^{\circ} \mathrm{C}$ in a humidified incubator with $5 \% \mathrm{CO} 2 / 95 \%$ air. Human genomic DNA extracted from HEK293 cells was used to amplify the FABP5 promoter fragment (positions -1250/-1) and subcloned into pGL3-Basic-luciferase vector (Promega, Madison, WI, USA). All cloned DNA fragments were confirmed by DNA sequencing. SH-SY5Y cells in $35 \mathrm{~mm}$ dishes were transfected with $2 \mu \mathrm{g}$ of FABP5-pGL3 vector, as well as $50 \mathrm{ng}$ of renilla luciferase plasmid (internal control) for $6 \mathrm{~h}$ using lipofectamine LTX and Plus Reagent (Invitrogen, Carlsbad, CA, USA) according to the manufacturer's protocol. After transfection, cells were treated with BSA-AA (arachidonic acid) and MF6 and maintained in D-MEM (1\% penicillin-streptomycin) without FBS for $24 \mathrm{~h}$. AA (Sigma, 10931, St Louis, MO, USA) and BSA (Sigma, A7030, fatty acid free) were used to prepare BSA-AA complexes at a 1:5 ratio mixed in binding buffer $(10 \mathrm{mM}$ Tris- $\mathrm{HCl}(\mathrm{pH} 8.0)$, $150 \mathrm{mM} \mathrm{NaCl}$ ) at $37^{\circ} \mathrm{C}$ for $30 \mathrm{~min}$. Firefly luciferase and renilla luciferase activities were measured with the dual-luciferase reporter assay kit (Promega) using a luminometer (Gene Light 55, Microtec, Funabashi, Japan). Relative luciferase activity was expressed as the ratio of firefly luciferase activity to renilla luciferase activity [25].

\subsection{Statistical Analysis}

The results are presented as box and whisker plots (median, first and third quartile, range), overlaid by dot plot of the raw data. Statistical analysis was conducted using SigmaPlot ${ }^{\circledR}$ version 14 (SYSTAT Software Inc., San Jose, CA, USA). Data from all experiments were analyzed by one-way analysis of variance (ANOVA) followed by Dunnett's test for multiple comparisons (results of concentration gradient and time gradient), or two-way ANOVA followed by Student-Newman-Keuls test for multiple comparisons (MF6 treatment groups). A value of $p<0.05$ was considered to reflect statistically significant differences.

\section{Results}

\subsection{Pharmacokinetics of MF6 in the Blood and Brain after $I / R$}

We initially determined whether MF6 could penetrate the blood-brain barrier (BBB) as a prerequisite step for evaluating the therapeutic effects of MF6 on cerebral ischemic injury. We measured MF6 concentrations in the plasma and brain tissues of mice after administering MF6 (3 mg/ $\mathrm{kg})$. The results revealed that MF6 easily entered the bloodstream. MF6 concentrations in the plasma of sham-operated mice increased rapidly within the first $3 \mathrm{~h}$ (15 min: $88.88 \pm 25.46 \mathrm{nM} ; 3 \mathrm{~h}: 514.95 \pm 66.12 \mathrm{nM})$, reached the maximum value after approximately $4 \mathrm{~h}(\mathrm{C} \max =522.18 \pm 74.33 \mathrm{nM})$ and then gradually decreased to $47.14 \pm 7.50 \mathrm{nM}$ by $48 \mathrm{~h}$ (Figure 2A). However, concentrations of MF6 in the brain did not increase in mice with I/R-induced BBB dysfunction (Figure 2B), indicating that MF6 penetrates to brain even in non-ischemic mice. Moreover, no significant difference was found in MF6 concentrations between the contralateral and ipsilateral portions of ischemic brains (Figure 2B). 
A

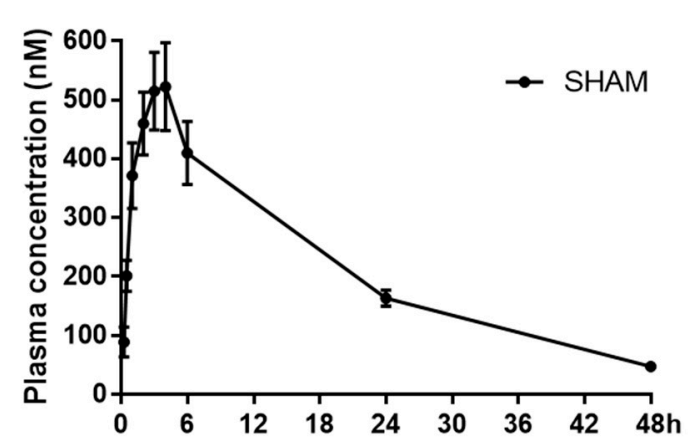

B

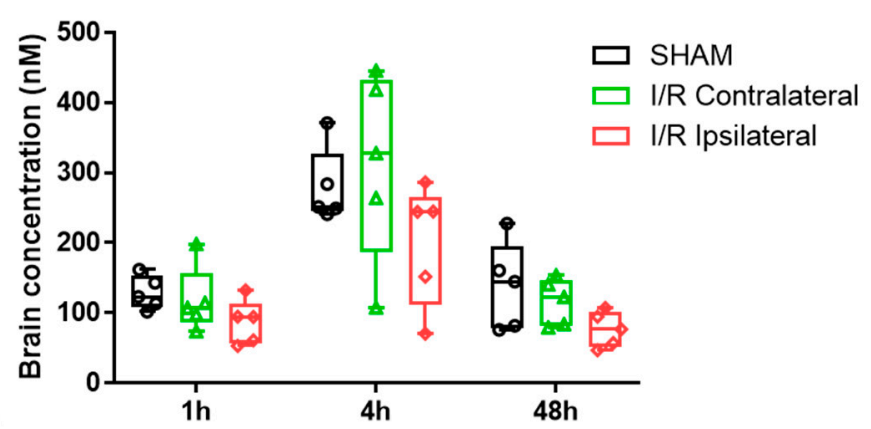

Figure 2. Pharmacokinetics of MF6 in the plasma and brain in sham and I/R mice. (A) MF6 plasma concentrations were measured at $0.25,0.5,1,2,3,4,6,24$ and $48 \mathrm{~h}$ after MF6 administration in sham mice ( $\mathrm{n}=5$ per group). The data shown in each represent the mean \pm SEM. (B) The MF6 concentrations in the contralateral and ipsilateral regions of the brains of sham and I/R mice were measured at 1, 4 and $48 \mathrm{~h}$ after MF6 administration ( $\mathrm{n}=5$ per group). No statistical difference was observed among the groups at the same time point by one-way analysis of variance (ANOVA) followed by Dunnett's test.

\subsection{MF6 Reduced Infarct Volumes and Ameliorated Neurological Deficits in I/R Mice}

We then examined whether MF6 treatment could reduce cerebral ischemic injury. Mice were treated with or without MF6 $(0.5,1$ or $3 \mathrm{mg} / \mathrm{kg}) 30 \mathrm{~min}$ after reperfusion. Mice with I/R surgery showed large infarct volumes (70.28 $3.19 \%)$ and MF6 treatment signif-icantly reduced infarct volumes in a concentration-dependent manner $(1 \mathrm{mg} / \mathrm{kg}$ group: $50.13 \pm 5.70 \%, p=0.021 \mathrm{vs}$. I/R group; $3 \mathrm{mg} / \mathrm{kg}$ group: $43.26 \pm 4.63 \%, p<0.001 \mathrm{vs}$. I/R group; Figure 3A,B). Moreover, MF6-treated I/R mice showed significantly decreased neurological deficits compared to those of the I/R group treated without MF6 $(1 \mathrm{mg} / \mathrm{kg}$ group: $p=0.034 ; 3 \mathrm{mg} / \mathrm{kg}$ group, $p=0.014 \mathrm{vs}$. I/R group; Figure $3 \mathrm{C}$ ). Next, we tested the optimal timing of MF6 treatment and confirmed that the time of MF6 administration after reperfusion was crucial for the therapeutic effects, with earlier treatment resulting in better outcomes. Administering MF6 $30 \mathrm{~min}$ after reperfusion was more effective $(46.64 \pm 3.01 \%$, $p=0.007 \mathrm{vs}$. I/R group, $76.66 \pm 3.10 \%$ ), than administering MF6 $1 \mathrm{~h}$ or $2 \mathrm{~h}$ after reperfusion $(60.70 \pm 9.88 \%, p=0.231 ; 63.98 \pm 8.80 \%, p=0.403$, respectively; Figure 3D-F).

To confirm the long-lasting protective effects of MF6 on I/R-induced cerebral infarct after the single administration, we evaluated the brain infract volumes and neurological scores at 7 days after reperfusion. The MF6 administration $(3 \mathrm{mg} / \mathrm{kg}$ ) reduced the cerebral infarction and improved the neurological deficits on day 7 after reperfusion $(25.93 \pm 2.09 \%$, $p<0.001$ vs I/R group, $55.79 \pm 3.32 \%$; Figure $3 \mathrm{H}, \mathrm{I})$ and improved the mortality of mice caused by ischemia ( $p=0.0276$ vs. I/R group; Figure 3J). Furthermore, we confirmed the protective effects of MF6 pre-administration in which MF6 was administered once $30 \mathrm{~min}$ before ischemia surgery. The MF6 pre-administration significantly reduced the infarct volume (I/R group: $72.88 \pm 6.24 \%)$ at $1 \mathrm{mg} / \mathrm{kg}(47.61 \pm 3.00 \%, p=0.012 \mathrm{vs}$. I/R group) and $3 \mathrm{mg} / \mathrm{kg}$ (39.31 $\pm 5.11 \%, p<0.001$ vs. I/R group) (Supplementary Materials Figure S1). Taken together, MF6 protects brain against I/R injury. Since the effects of $3 \mathrm{mg} / \mathrm{kg}$ MF6 treatment were re-productive, we chose the dose of $3 \mathrm{mg} / \mathrm{kg}$ as the optimum concentration for the subsequent experiments. 
A

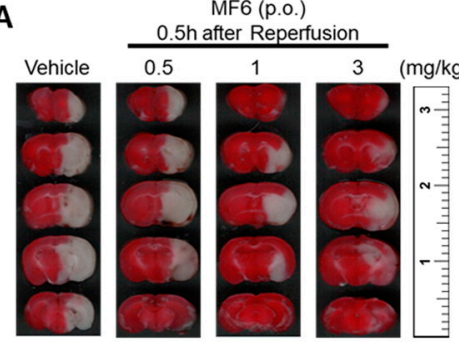

D
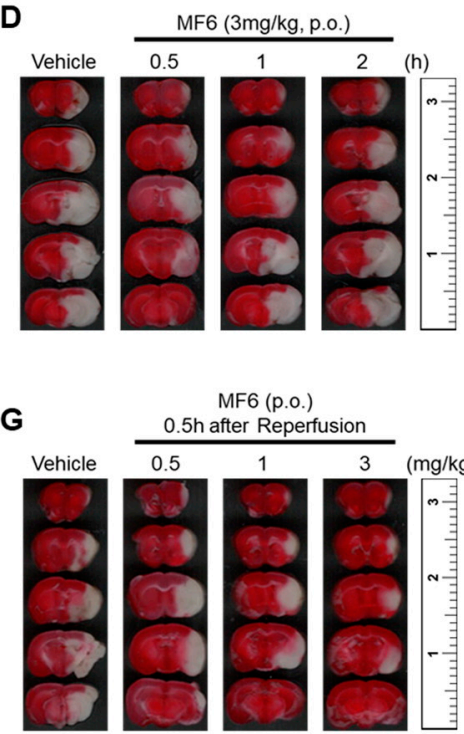

MF6 (p.o.) $0.5 \mathrm{~h}$ after Reperfusion
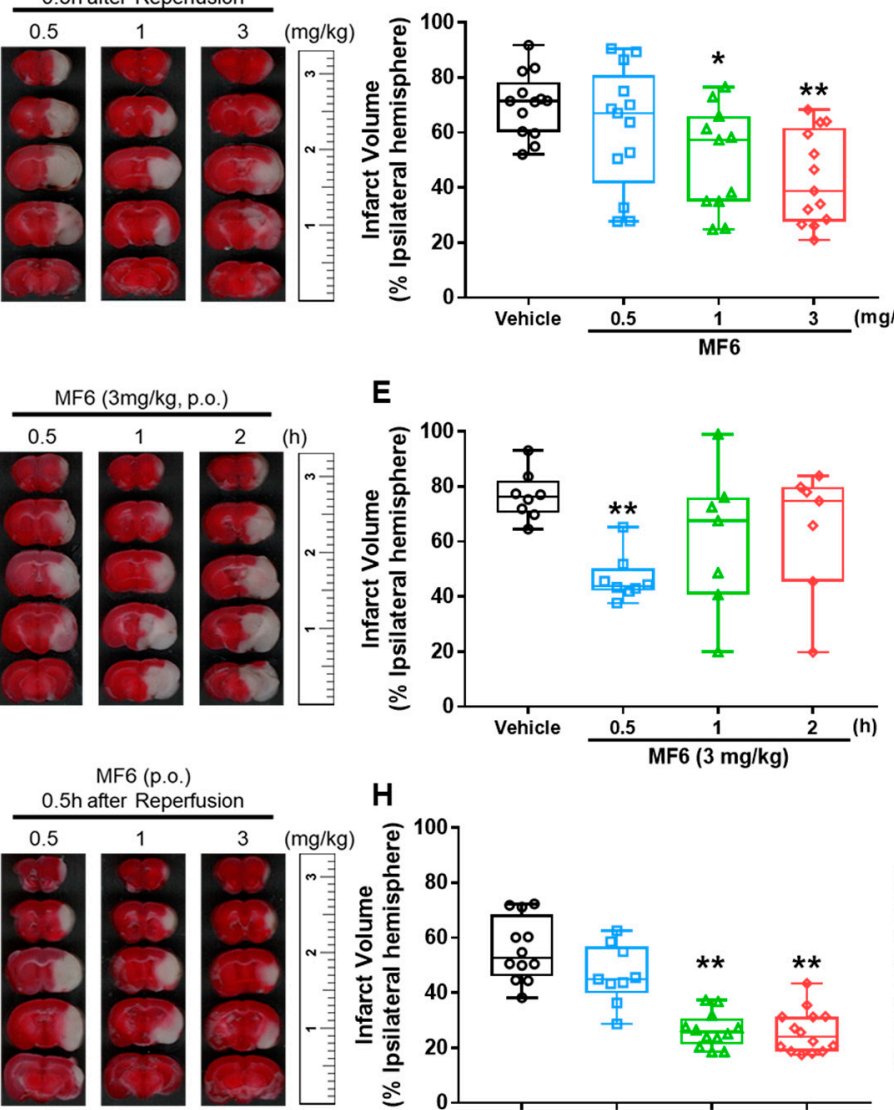

E
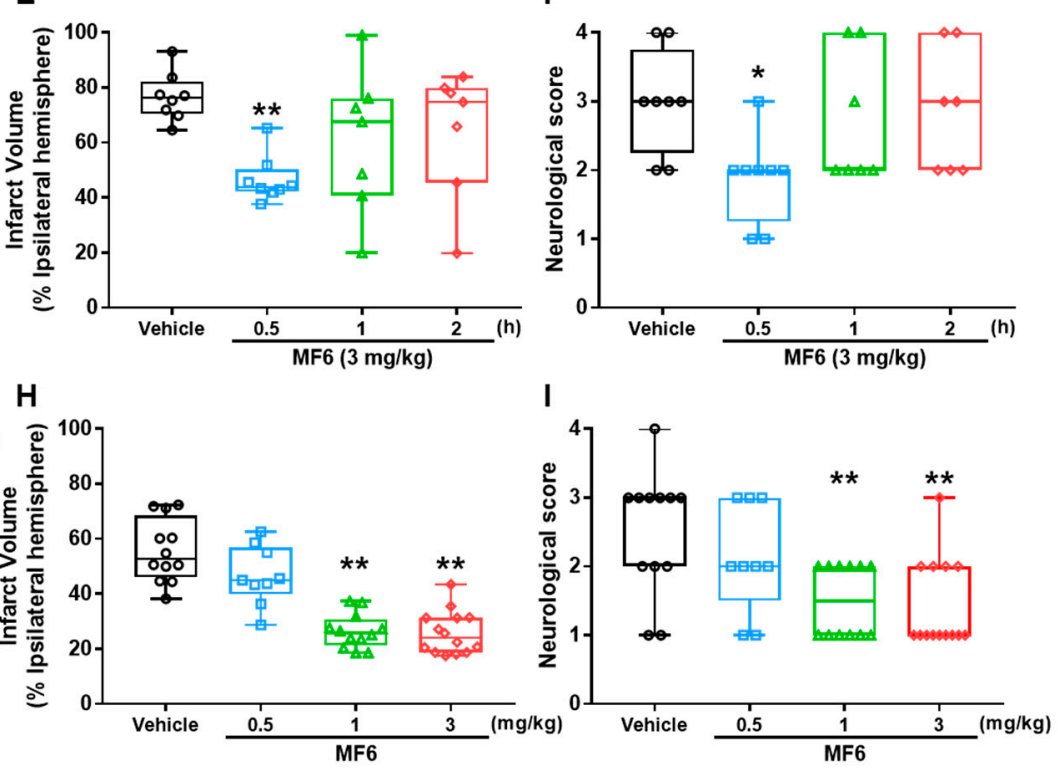

$\mathbf{J}$

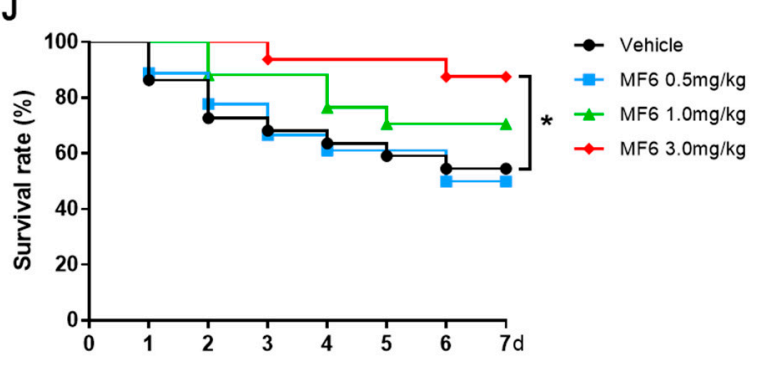

Figure 3. Effects of MF6 post-treatment on I/R injury in mice. Mice were subjected to tMCAO for $2 \mathrm{~h}$. (A-C) MF6 was administrated at different concentrations $(0.5,1$ or $3 \mathrm{mg} / \mathrm{kg}) 30 \mathrm{~min}$ after reperfusion. Representative images of TTC staining (A), quantitative analysis of the infarct volumes (B) and neurological deficits (C) at $24 \mathrm{~h}$ after reperfusion ( $\mathrm{n}=11-13)$. (D-F) MF6 (3 mg/kg) was administrated at $0.5,1$ or $2 \mathrm{~h}$ after reperfusion. Representative images of TTC staining (D), quantitative analysis of infarct volumes (E) and neurological deficits (F) at $24 \mathrm{~h}$ after reperfusion (n = 7-8). (G-J) MF6 was administrated with different concentrations $(0.5,1,3 \mathrm{mg} / \mathrm{kg}) 30 \mathrm{~min}$ after reperfusion. Representative images of TTC staining $(\mathbf{G})$, quantitative analysis of infarct volume $(\mathbf{H})$ and neurological deficits (I) at day 7 after reperfusion. The number of living animals in each group every day was recorded, and survival rate (J) was calculated ( $\mathrm{n}=9-14) .{ }^{*} p<0.05,{ }^{* *} p<0.01$ vs. the I/R-treated group with the CMC group (vehicle). Differences were statistically analyzed using one-way analysis of variance (ANOVA) followed by Dunnett's test.

\subsection{I/R Induced FABP3, FABP5 and FABP7 Protein Expression in Mouse Brains}

As previous findings indicated that the FABP5 and FABP7 proteins were significantly upregulated in post-ischemic adult monkey brains [27,28], we hypothesized that the FABP3, FABP5 and FABP7 proteins might also be upregulated in ischemic mouse brains. We measured protein-expression levels in the half-brain region including the cortex and striatum (Figure 4A), as previously described [25]. In the right ischemic hemisphere (ipsilateral 
area), FABP3 significantly increased at $12 \mathrm{~h}$ after reperfusion ( $p=0.004 \mathrm{vs.} \mathrm{sham} \mathrm{group)} \mathrm{and}$ maintained high protein-expression levels until $48 \mathrm{~h}$ ( $24 \mathrm{~h}: p=0.024 \mathrm{vs}$. sham group; $48 \mathrm{~h}$ : $p=0.047$ vs. sham group). I/R also significantly upregulated FABP3 expression in the left, non-ischemic hemisphere (contralateral area; $12 \mathrm{~h}: p=0.001 \mathrm{vs}$. sham group; $24 \mathrm{~h}: p=0.047$ vs. sham group), although the trend was weaker than observed with the ipsilateral areas and declined after $24 \mathrm{~h}$ (Figure 4C). Moreover, FABP5 and FABP7 expression were also upregulated in ipsilateral brain tissues (Figure $4 \mathrm{D}, \mathrm{E}$ ), and their expression levels increased faster than that of FABP3 (FABP3: $6 \mathrm{~h}: p=0.088$ vs. sham group) and had significantly increased at $6 \mathrm{~h}$ post-reperfusion (FABP5: $p=0.016$ vs. sham group; FABP7: $p=0.048$ vs. sham group). Specifically, FABP7 expression did not peak until $24 \mathrm{~h}$. However, the rate of FABP7 upregulation was stronger than that of FABP5 in contralateral brain tissues. All considered, these results show that I/R upregulated the FABP3, FABP5 and FABP7 proteins in a time-dependent manner in the whole brains of mice.

A

D

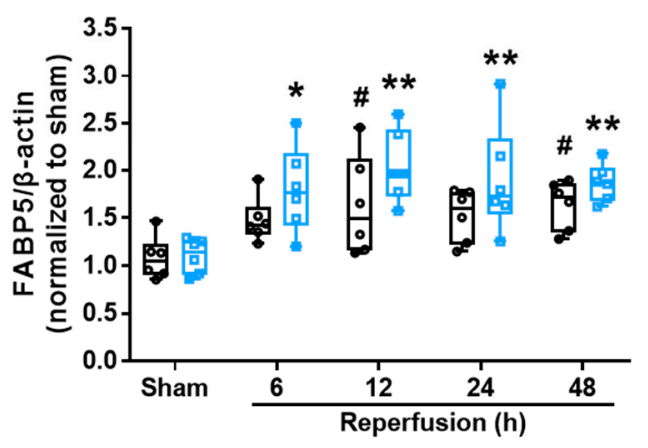

C

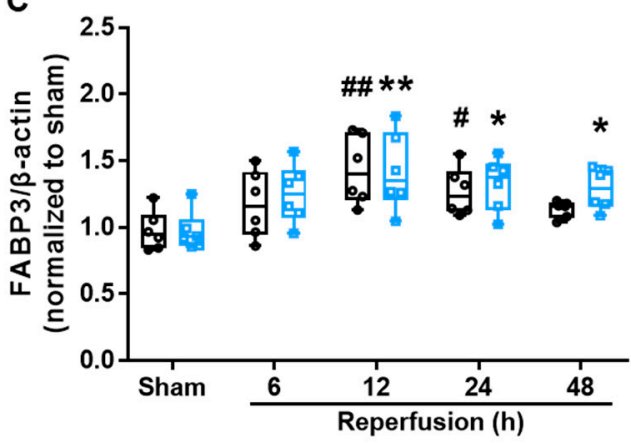

E

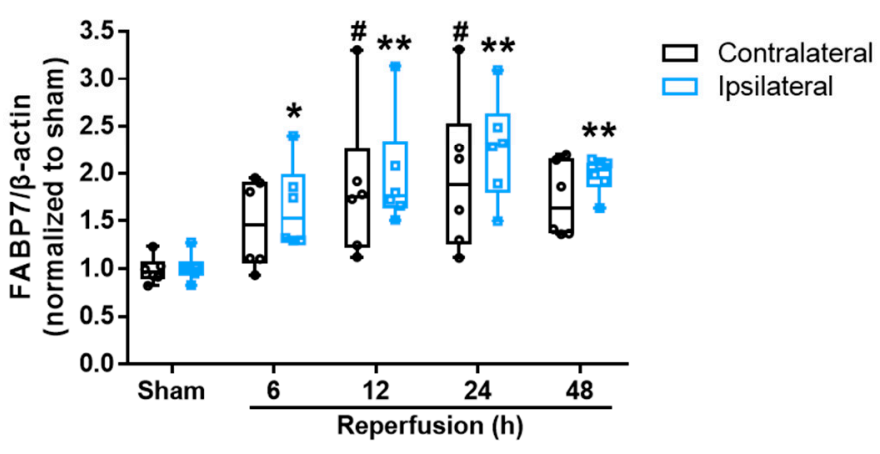

Figure 4. Effects of I/R injury on FABP3, FABP5 and FABP7 expression levels in the brain. (A) The locations of samples. Brains were cut into four slices (2-mm thick) from the front of the cortex. The second slices (designated as con and ips slices) of the brain, including the cortex and striatum, were used for Western blot analysis and $\mathrm{PGE}_{2}$-content analysis in the following experiments. (B-E) Mice were subjected to right tMCAO for $2 \mathrm{~h}$. At 6, 12, 24 and $48 \mathrm{~h}$ after reperfusion, the second slice of the right brain (ipsilateral) and the left brain (contralateral) areas were collected for Western blot analysis of FABPs levels. (B) Representative images of Western blots. Quantitative analyses of FABP3 (C), FABP5 (D) and FABP7 (E) expression levels in contralateral (black) and ipsilateral (blue) areas of the brains. ${ }^{\#} p<0.05,{ }^{\# \#} p<0.01$ vs. the sham group (contralateral); ${ }^{*} p<0.05,{ }^{* *} p<0.01$ vs. the sham group (ipsilateral) ( $\mathrm{n}=6$ per group). Differences were statistically analyzed using one-way analysis of variance (ANOVA) followed by Dunnett's test.

\subsection{I/R-Induced FABPs Were Expressed in Specific Cells in the Cortex}

We investigated the phenotypes of FABP3-, FABP5- and FABP7-positive cells in the cortical area of the penumbra (Figure 5A) at $12 \mathrm{~h}$ after reperfusion. We co-stained the FABP3, FABP5 and FABP7 proteins and cell type-specific markers, which included NeuN for neurons, GFAP for astrocytes, Olig2 for oligodendrocytes and Iba1 for microglia. In non-ischemic mouse cortexes, FABP3 was almost co-expressed with NeuN (Figure 5B1) but not with Iba1 (Figure S2A), indicating that FABP3 was localized to neurons. I/R-induced FABP3 expression also occurred almost in neurons (Figure 5B2). A previous report showed 
that FABP5 was expressed both in neurons and glial cells [10]. In agreement, we found that FABP5 was expressed in Olig2-positive cells (Figure 5D1), expressed at a slightly lower level in NeuN-positive cells (Figure 5C1) and weaker still in GFAP-positive cells (Figure S3A) in non-ischemic mouse cortexes, but that FABP5 was not co-expressed with Iba1 (Figure S2B). After I/R, FABP5 was significantly expressed in oligodendrocytes (Olig2 ${ }^{+}$cells, Figure 5D2) and neurons $\left(\mathrm{NeuN}^{+}\right.$cells, Figure 5C2), and marginally expressed in astrocytes (GFAP ${ }^{+}$ cells, Figure S3B). Furthermore, FABP7 was usually expressed in astrocytes (GFAP ${ }^{+}$cells, Figure 5E1) and oligodendrocytes (Olig2 ${ }^{+}$cells, Figure 5F1) in the cortex, and I/R-induced FABP7 expression was mainly observed in astrocytes (Figure 5E2) but was not obviously induced in oligodendrocytes (Figure 5F2). In addition, FABP7 was not co-expressed with Iba1 (Figure S2C).

A
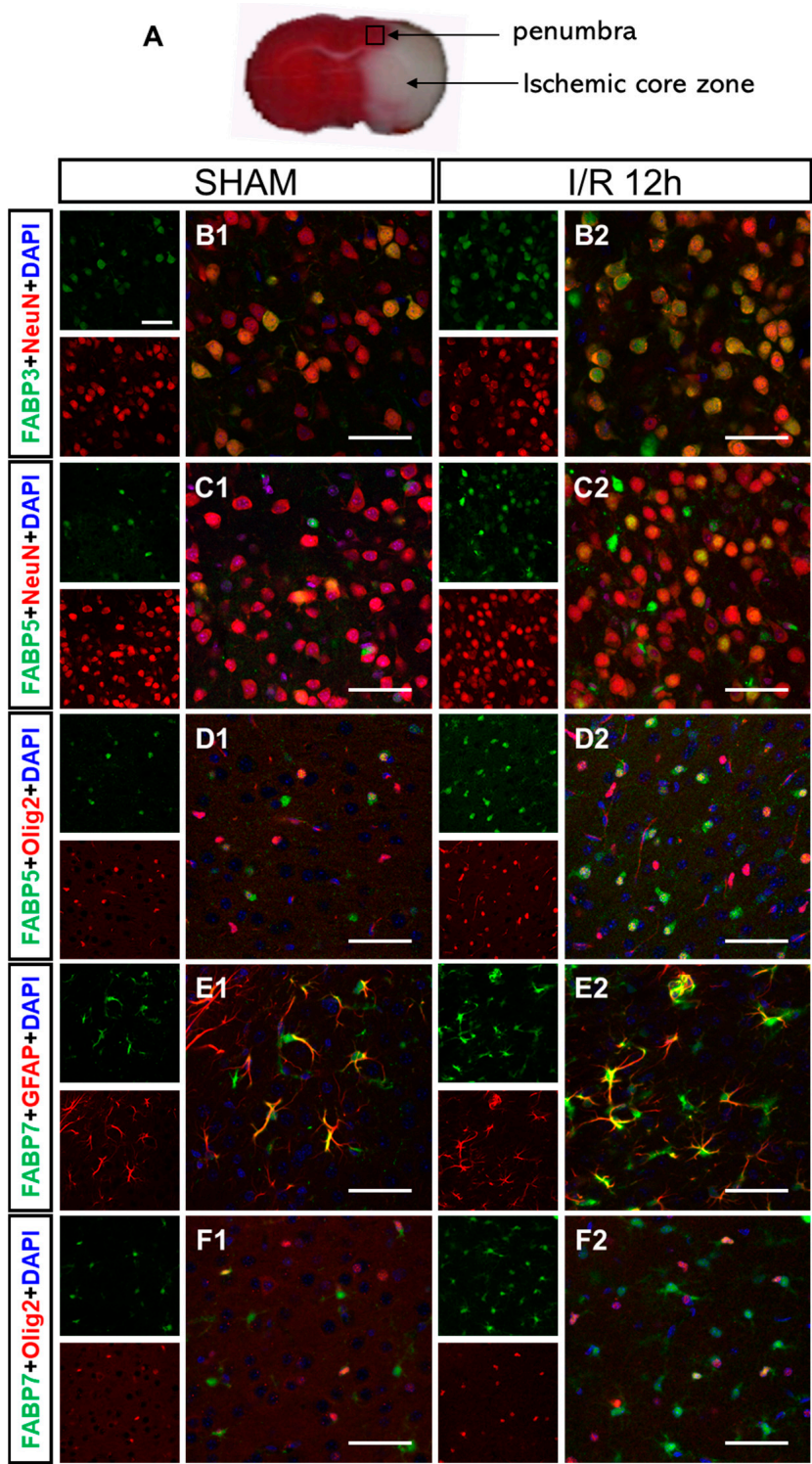

Figure 5. Immunofluorescence of FABP3, FABP5 and FABP7 in the cortexes of sham and I/R mice. (A) Representative micro-graphs of immunofluorescence staining of the cortical penumbra region (shown in the black box area) at $12 \mathrm{~h}$ after reperfusion. (B) Double staining for FABP3 (green) and NeuN (a neuronal marker, red) expression in sham mice (B1) and I/R mice (B2, ipsilateral). (C,D) Double staining for FABP5 (green) and NeuN (red; C) or Olig2 (an oligodendrocyte marker, red; D) in sham mice and I/R mice (ipsilateral). (E,F) Double staining for FABP7 (green) and GFAP (an as-trocyte marker, red; E) or Olig2 (red; F). Scale bar $=50 \mu \mathrm{m}$. The two small images on the left show immunofluorescence for FABPs and cell markers, whereas the larger image on the right is a merged image. 


\subsection{MF6 Suppressed FABP3, FABP5 and FABP7 Protein Upregulation in I/R Mouse Brains}

FABP3, FABP5 and FABP7 expression levels significantly increased at $12 \mathrm{~h}$ postreperfusion, without particularly serious destruction to the structures of brain tissues. Therefore, we next determined whether MF6 could prevent activation of the FABP3, FABP5 and FABP7 proteins at $12 \mathrm{~h}$ after reperfusion. MF6 slightly attenuated the increase in FABP3 protein expression ( $p=0.034$ vs. vehicle-treated I/R group) in the ischemic area (ipsilateral), but not in the contralateral area ( $p=0.851$ vs. vehicle-treated I/R group), as shown in Figure 6B. FABP5 and FABP7 expression in ischemic area were significantly suppressed by MF6 treatment (both: $p<0.001$ vs. vehicle-treated I/R group), and FABP5 expression in the contralateral area was also significantly suppressed ( $p=0.015$ vs. vehicle-treated I/R group), but FABP7 was not ( $p=0.051$ vs. vehicle-treated I/R group) (Figure 6C,D). Moreover, MF6 did not affect FABP3, FABP5 and FABP7 protein levels in non-ischemic mouse brains (sham mice). The present Western blotting data showed that MF6 ameliorated the effects of I/R injury by inhibiting FABP3, FABP5 and FABP7 upregulation.

A

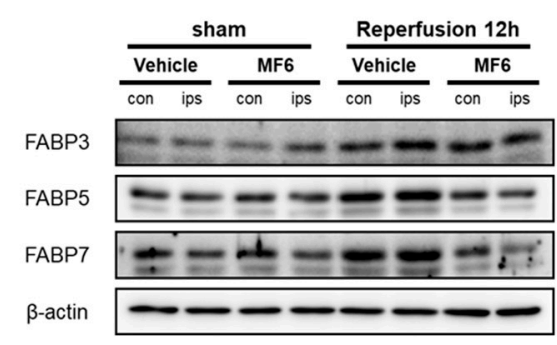

C

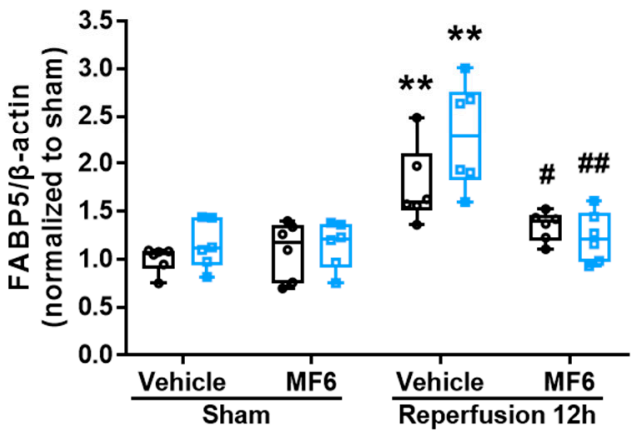

B

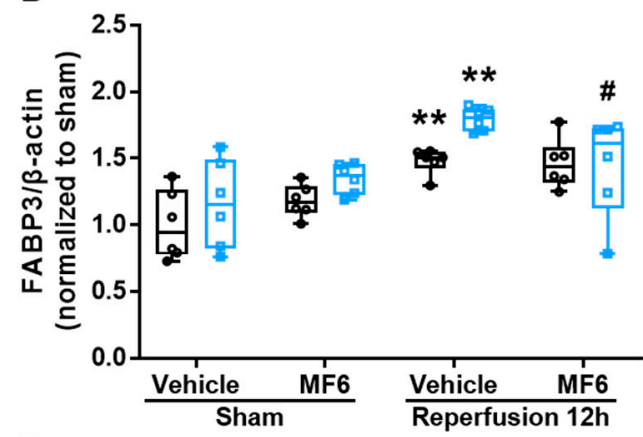

D

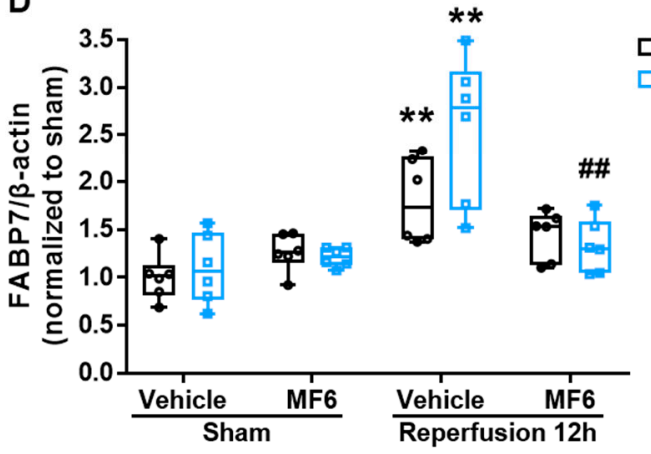

Figure 6. Effects of MF6 administration on FABP3, FABP5 and FABP7 expression levels in I/R mice. Mice were subjected to right $\mathrm{tMCAO}$ for $2 \mathrm{~h}$ and administered $3 \mathrm{mg} / \mathrm{kg}$ MF6 at $30 \mathrm{~min}$ after reperfusion. At $12 \mathrm{~h}$ after reperfusion, the second slice of the right (ipsilateral) and left (contralateral) brain areas, including the cortex and striatum, were used for Western blot analysis of FABP levels. (A) Representative images of Western blots. Quantitative analyses of FABP3 (B), FABP5 (C) and FABP7 (D) proteins expression levels in the contralateral (black) and ipsilateral (blue) regions of the brains. ${ }^{* *} p<0.01 \mathrm{vs.}$ the sham-treated group, administered the vehicle (contralateral/ipsilateral); ${ }^{\#} p<0.05,{ }^{\# \#} p<0.01$ vs. the I/R-treated group, administered the vehicle (contralateral/ipsilateral) $(n=6$ per group). Differences were statistically analyzed using two-way analysis of variance (ANOVA) followed by Student-Newman-Keuls test.

\subsection{MF6 Prevented AA-Induced FABP5 Upregulation in SH-SY5Y Cells}

To elicit the mechanism of MF6 on FABP induction, we focused on FABP5 gene expression because the neuronal expression of FABP5 is pronounced compared to FABP3. Moreover, the stimulation with arachidonic acid (AA) increases the activation of PPAR $\beta / \delta$ in MCF-7 cells [29] and PPAR $\beta / \delta$ agonist, GW0742 up-regulates FABP5 expression in PC3M cells [30]. SH-SY5Y human neuroblastoma cells were used to investigate the effects of AA on FABP5 transcriptional activity. When SH-SY5Y cells were exposed to AA for $24 \mathrm{~h}$, the FABP5 promoter activity increased significantly (30 $\mu \mathrm{M}$ AA, 1.89-fold the control cells 
level, $p<0.001$ ) and AA effects was bell shape. (Figure 7A). MF6 treatment with $1 \mu \mathrm{M}$ inhibited the increased FABP5 promoter activity by AA ( $p=0.001$ vs. vehicle-treated AA group, Figure 7B). Taken together, MF6 reduces FABP5 protein expression by inhibiting FABP5 transcription activity.

A

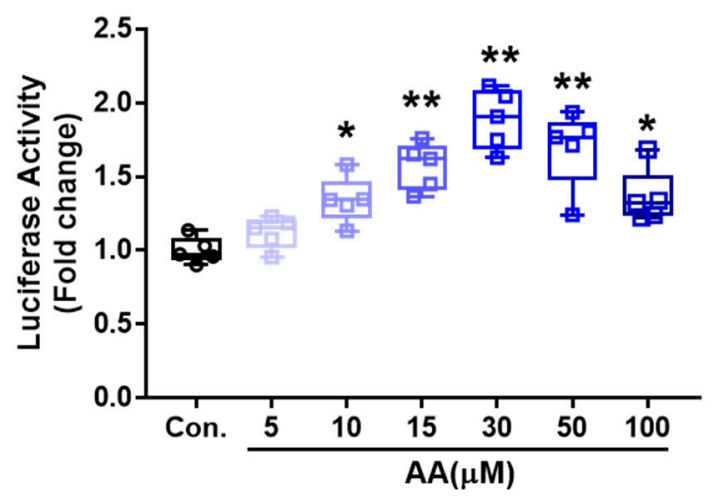

B

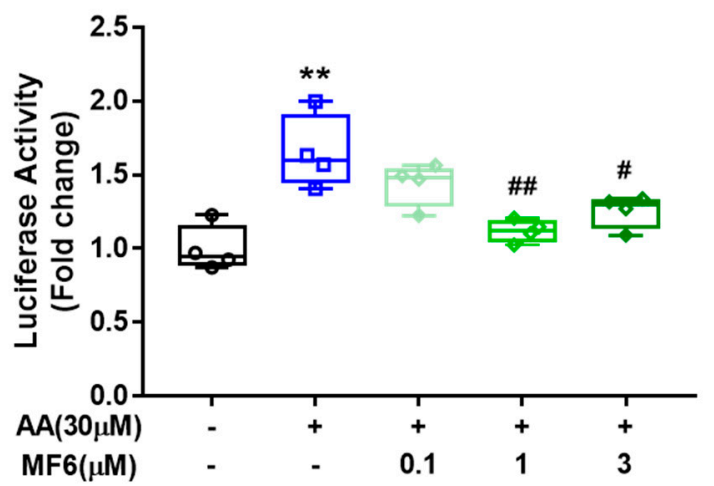

Figure 7. Effects of MF6 administration on AA-induced FABP5 transcriptional activity in SH-SY5Y cells. SH-SY5Y cells were co-transfected with FABP5-pGL3 and Renilla luciferase reporter vectors for 6h. (A) After transfection, cells were stimulated with different doses of AA $(5 \mu \mathrm{M}, 10 \mu \mathrm{M}, 15 \mu \mathrm{M}, 30 \mu \mathrm{M}, 50 \mu \mathrm{M}$ or $100 \mu \mathrm{M})$ for $24 \mathrm{~h}$ (n = 5 per group). (B) After transfection, cells were treated with AA/BSA and MF6 $(0.1 \mu \mathrm{M}, 1 \mu \mathrm{M}$ or $3 \mu \mathrm{M})$ at the same time for $24 \mathrm{~h}(\mathrm{n}=4$ per group). Promoter activity were represented as firefly/Renilla luciferase activity and were normalized to control cells (without AA treatment). ${ }^{*} p<0.05,{ }^{* *} p<0.01$ vs. the BSA-treated cells (Con.); ${ }^{\#} p<0.05,{ }^{\# \#} p<0.01$ vs. the AA and vehicle-treated cells. Differences were statistically analyzed using Student's $t$-test or one-way analysis of variance (ANOVA) followed by Dunnett's test.

3.7. MF6 Suppressed the Microsomal Prostaglandin E Synthase-1 (mPGES-1)-PGE Signaling Pathway in I/R Mouse Brains

Post-ischemic inflammation is an important part of the injury mechanism occurring in ischemic stroke. Accumulation of $\mathrm{PGE}_{2}$ and its synthase mPGES-1 aggravates cerebral $\mathrm{I} / \mathrm{R}$ injury [31]. Therefore, we examined changes of mPGES-1 protein expression and $\mathrm{PGE}_{2}$ levels after reperfusion in mice. Our results showed that I/R significantly increased mPGES-1 protein expression in ischemic and contralateral areas, and both peaked at $24 \mathrm{~h}$ after reperfusion ( $p<0.001$ vs. sham group) (Figure $8 \mathrm{~A}$ ). After $12 \mathrm{~h}$ of reperfusion, the $\mathrm{PGE}_{2}$ levels in ischemic brains were significantly higher than those of sham-operated brains (ipsilateral: $p<0.001$ vs. vehicle-treated sham group, contralateral: $p=0.003$ vs. vehicle-treated sham group) (Figure 8D). Moreover, MF6 treatment significantly reversed I/R-induced increases in mPGES-1 expression ( $p=0.001$ vs. vehicle-treated I/R group) and $\mathrm{PGE}_{2}$ levels ( $p=0.001$ vs. vehicle-treated $\mathrm{I} / \mathrm{R}$ group) in ipsilateral areas without contralateral area (mPGES-1: $p=0.435, \mathrm{PGE}_{2}: p=0.304$; Figure 8C,D). By immunostaining mPGES-1-positive cells with cell-type specific markers, we observed that mPGES-1 was expressed in $\mathrm{NeuN}^{+}$neurons but not in $\mathrm{GFAP}^{+}$astrocytes or Olig2 ${ }^{+}$oligodendrocytes in the cortexes of sham mice (Figure $8 \mathrm{~B}$ ) and that I/R-induced increases also occurred in neurons. 

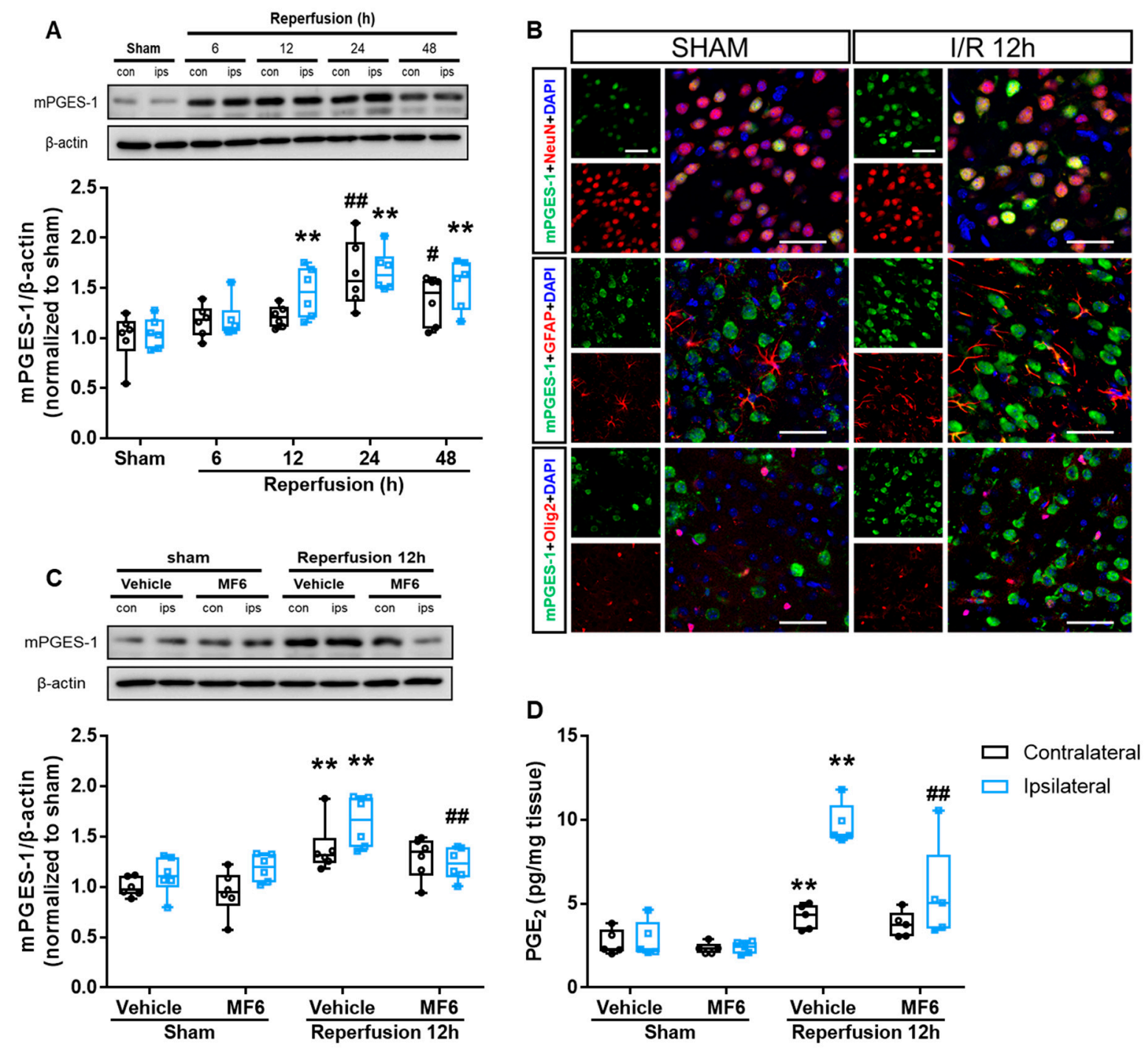

Figure 8. Effects of MF6 administration on mPGES-1 expression and PGE 2 levels in I/R mice. (A) Mice were subjected to $\mathrm{tMCAO}$ for $2 \mathrm{~h}$. Representative Western blot images and quantitative analyses of mPGES-1 protein expression in contralateral and ipsilateral brain regions at 6,12, 24 and $48 \mathrm{~h}$ after reperfusion. ${ }^{\#} p<0.05,{ }^{\#} p<0.01$ vs. the sham group (contralateral); ${ }^{* *} p<0.01$ vs. the sham group (ipsilateral) ( $\mathrm{n}=6$ per group). (B) Representative micrographs of immunostaining for mPGES-1 (green) and NeuN, GFAP or Olig2 (red) in the cortical penumbra region at $12 \mathrm{~h}$ after reperfusion. Scale bar $=50 \mu \mathrm{m}$. (C) Mice were subjected to tMCAO for $2 \mathrm{~h}$ and administered $3 \mathrm{mg} / \mathrm{kg} \mathrm{MF} 6$ at $30 \mathrm{~min}$ after reperfusion. Representative Western blot images and quantitative analyses of mPGES-1 protein expression in contralateral and ipsilateral brain regions at $12 \mathrm{~h}$ after reperfusion in I/R mice, treated with MF6 30 min after reperfusion ( $\mathrm{n}=6$ per group). (D) $\mathrm{PGE}_{2}$ levels in contralateral and ipsilateral regions (Figure $4 \mathrm{~A}$ ) of sham and I/R mice treated with or without MF6 ( $\mathrm{n}=5$ per group). ${ }^{* *} p<0.01$ vs. the sham-treated group, administered the vehicle (contralateral/ipsilateral); ${ }^{\#} p<0.05$, $\#$ \# $p<0.01$ vs. the I/R-treated group, administered the vehicle (contralateral/ipsilateral). Differences were statistically analyzed using one-way analysis of variance (ANOVA) followed by Dunnett's test (A) or two-way analysis of variance (ANOVA) followed by Student-Newman-Keuls test (C,D).

\section{Discussion}

In this study, we demonstrated that MF6 decreased brain infarction volumes and neurological deficits in mice subjected to tMCAO and reperfusion by inhibiting FABP3, FABP5 and FABP7 expression in the brain. The FABP inhibitor MF6 inhibited the mPGES1-dependent induction. These results supported our hypothesis that brain FABPs are key molecules in ischemic stroke and that their excessive activation exacerbates brain 
inflammation through mPGES-1. Therefore, our findings show that MF6 was beneficial for treating ischemic stroke.

In this study, we first discovered that I/R significantly induced FABP3, FABP5 and FABP7 protein expression in the mouse brain, especially that of FABP5 and FABP7. Our results were consistent with several previous findings showing that FABP5 and FABP7 proteins were abundantly expressed in the post-ischemic hippocampus in adult monkeys [28] and that FABP7 gradually increased in the cerebellar cortex of adult monkeys after ischemia, reaching a maximum at day 15 [27]. These results imply that FABP3, FABP5 and FABP7 protein induction appears to exhibit beneficial of detrimental effects for ischemic injury. Moreover, co-staining FABPs in different cell types in the cortical area of the penumbra suggests that increased FABP3, FABP5 and FABP7 expression occurred only in specific cells expressing these proteins before ischemia. FABP3 immunoreactivity increased in neurons, whereas FABP7 was predominantly expressed and increased in astrocytes. In contrast, FABP5 expression increased both in neurons and oligodendrocytes. The localization of FABP3, FABP5 and FABP7 are consistent with previous studies [10,11,32,33].

Under pathological conditions, elevated FABP3 expression level promotes embryonic cancer cell apoptosis [34] and cardiomyocyte apoptosis during myocardial infarction [35]. These studies proposed that FABP3 overexpression reduces mitochondrial activity characterized by lower ATP synthesis and a lower mitochondrial membrane potential, as well as increased reactive oxygen species (ROS) levels and abnormal mitochondrial morphology. FABP3 is also critical for the loss of mitochondrial activity and ROS production during the neurodegenerative process in dopaminergic neurons [36]. In contrast, FABP5 expression is elevated in CA1 neurons (which are apoptotic after ischemia), but was unchanged in DG neurons that remained relatively stable after ischemia in the hippocampus of adult monkeys, suggesting that FABP5 is likely involved in the survival of hippocampal neurons [37].

Furthermore, FABP7 can participate in the proliferation of hippocampal astrocytes after ischemia [37]. However, it remains unclear whether the ischemia-induced enhancement of reactive astrocytes and FABP7 levels elicit beneficial or deleterious effects in neurons $[38,39]$. Astrocytes expressing FABP7 are crucial for the normal development of dendritic arbors, the formation of and transmission through the excitatory synapses of cortical neurons [40], and even increases the loss of ventral horn neurons in FABP7knockout mice with spinal cord injury [41]. Conversely, FABP7 overexpression can directly promote a nuclear factor-kappa B (NF- $\mathrm{kB}$ )-driven pro-inflammatory response in astrocytes of mice with amyotrophic lateral sclerosis and can ultimately reduce motor neuron survival [42], whereas FABP7 knockdown in the developing brain can increase the proportion of neurons [43,44]. Based on these findings, we hypothesized that FABPs elicit detrimental effects on mitochondrial homeostasis and neuroinflammation, whereas FABP7 is partially required for neuronal differentiation in the developmental stages. However, further studies are required to identify the roles of FABP3, FABP5 and FABP7 after I/R injury.

In addition, we identified important roles for the elevated FABP levels in non-ischemic areas (left hemispheres) after brain ischemia. Previous reports indicated that ischemic lesions cause metabolite changes [45], edema and decreased cerebral blood flow [46] in remote non-ischemic regions. However, in non-ischemic areas, ischemia does not directly cause these changes, and some intermediate incentives are necessary to explain the induction processes. In addition to cerebral ischemia, many findings have also confirmed that in other neurodegenerative disorders (such as Alzheimer's disease and Parkinson's disease), cerebrospinal fluid (CSF) FABP3 levels [47,48] and serum FABP7 levels [49] are elevated in patients, and FABP5 is upregulated in a mouse model of Alzheimer's disease [50]. Since neuroinflammation is a key contributing factor for neurodegenerative diseases, the high levels of pro-inflammatory cytokines, such as tumor necrosis factoralpha (TNF- $\alpha$ ), interleukin (IL)-1 $\beta$ and IL-6 [51-53], are found in the brain and CSF of patients. We speculated that pro-inflammatory cytokines spread from the ischemic core lesion to non-ischemic areas. FABP5 expression is upregulated by lipopolysaccharide (LPS) in human lung epithelial BEAS-2B cells [54] or by TNF- $\alpha$ in human aortic endothelial 
cells [55]. FABP7 levels are upregulated in spinal cord astrocytes in a mouse model of experimental autoimmune encephalomyelitis [56] and in primary cortical neuronal cultures after exposure to glutamate [57]. Taken together, FABPs trigger the neuronal injury in non-ischemic regions. However, further studies are required to confirm the FABP-induced neuronal injury.

In this study, we administrated MF6 to treat I/R injury in mice, and MF6 effectively reduced infarct volumes and lessened neurological dysfunction, suggesting that it can potentially be used as a therapeutic drug for ischemic injury. Regarding the site of action of MF6, we previously determined that MF6 significantly inhibited FABP3 and FABP5 protein expression and had a high affinity for both proteins [23]. Based on the above results, we envisioned the mechanisms underlying the ameliorative effects of MF6 on an ischemic injury. After administering MF6, it quickly entered the brain through the BBB and associated with FABP3 and FABP5 to different degrees to block their activities, which inhibited FABP-induced signaling pathways such as apoptosis and inflammation $[8,34]$. Consequently, the degree of cerebral ischemic injury was reduced, and then the weakened injury in turn lowered the stimulation of FABP expression levels.

We recently found that FABP5 causes cell death under oxidative stress in glial cells [58]. When cells were exposed with psychosine, a phospholipase A2 activator, it caused the mitochondria-induced glial death via forming mitochondrial macropores with voltagedependent anion channel (VDAC-1) and BAX [58]. The MF6 treatment completely abolished the psychosine-induced mitochondrial injury. Even though cell type expressed FABP5 are different between neuronal cells in brain ischemia in the present study and glial cells treated with psychosine by Cheng et al, FABP5-mediated mitochondrial injury in part mediates the neuronal death in the brain ischemia.

FABPs themselves may participate in the FABP upregulation, because MF6 inhibited the FABP5 transcriptional activity induced by AA. AA is known to elevate in during ischemia [59] and it is also a strong ligand of FABP3 and FABP5 [23]. Moreover, AA is an endogenous activator of PPARs [60]. In this context, we speculate that FABPs transport AA from the cytoplasm to the nucleus to promote the activities of PPARs [61].

In addition, there are several the binding sites (PPRE) of PPARs on the promoter region of FABP3, FABP5 and FABP7 genes and the activations of PPAR $\beta / \delta$ and PPAR $\gamma$ mediate the expression of FABP5 [30,62]. Taken together, MF6 may reduce functions of FABPs, thereby inactivating transcriptional activities through PPARs. However, to resolve the precise interaction between PPAR subclasses $(\alpha, \beta / \delta$ and $\gamma)$ and FABP isoforms in neuronal cells, further extensive studies are required.

As a major inflammatory mediator, $\mathrm{PGE}_{2}$ is involved in the development of injury in several inflammatory neurological diseases, such as stroke and Alzheimer's disease [63,64]. In this study, we confirmed that ischemia induced $\mathrm{PGE}_{2}$ accumulation in the brain, which was caused by the activation of mPGES-1, as previously reported [31]. Since COX-2 level is not changed in the non-ischemic regions [31], the increased mPGES-1 in the contralateral region may count for the increased $\mathrm{PGE}_{2}$ level. Since PPAR $\gamma$ activation enhances FABP5 mRNA expression and increase the levels of $\mathrm{mPGES}-1 \mathrm{mRNA}$ and $\mathrm{PGE}_{2}$ in porcine trophoblast cells, and a PPAR $\gamma$ antagonist blocked their up-regulation [62], the regulation of the FABP5 and mPGES-1 upregulation may depend on PPAR $\gamma$. Furthermore, FABP5 inhibition reduces the nuclear transport of NF- $\mathrm{kB}$, thereby decreasing mPGES- 1 expression and $\mathrm{PGE}_{2}$ synthesis [65], NF- $\mathrm{kB}$ also induces the expression of various pro-inflammatory genes [66] and induces neuronal death in cerebral ischemia [67]. In this context, both PPAR and NF- $\mathrm{kB}$ may underly the mechanism of upregulation of mPGES-1-PGE 2 in brain ischemia. Moreover, our findings showed that administering MF6 inhibited FABP3 and FABP5 expression and strongly prevented the induction of mPGES- 1 expression and $\mathrm{PGE}_{2}$ levels in the brain of I/R mice, indicating that the activation of FABP-mPGES-1-PGE ${ }_{2}$-signaling pathways promotes ischemic injury. However, it is unclear whether one FABP or FABP3, FABP5 and FABP7 collectively induced mPGES-1 after ischemia. This question requires further investigation, but our data indicated that at least FABP5 was present. Further 
extensive studies are required to define whether FABP3 or FABP7 is involved in PPAR and NF- $\mathrm{KB}$ signaling and whether MF6 treatment inhibits the activity of NF- $\mathrm{KB}$.

Our present results first defined that FABP inhibitor MF6 can inhibit ischemic brain injury by inhibiting the expression and function of activated FABPs after ischemia. Further extensive studies are required to confirm the detrimental functions of FABPs in neuron and glia by using the knockout mice of FABPs. In addition, MF6 has high affinity for FABP7 as compared to FABP3 and FABP5. Since FABP7 is extensively expressed in the astrocytes, the effect of MF6 on the $\mathrm{PGE}_{2}$ production should be defined in the astrocytes after brain ischemic injury.

In summary, the present study suggested that increased FABP3, FABP5 and FABP7 expression in the brain is a novel biochemical marker of cerebral ischemia and that the FABP inhibitor, MF6 inhibited their expression levels to play a neuroprotective role in cerebral I/R in mice.

Supplementary Materials: The following are available online at https:/ /www.mdpi.com/article/10 .3390 /biomedicines9050529/s1, Figure S1: Effects of MF6 pre-treatment on ischemia/reperfusion injury in mice, Figure S2: Immunofluorescence of FABP3, FABP5 and FABP7 proteins, as well as Iba1 (a marker of microglia), in the cortexes of sham and ischemia/reperfusion mice, Figure S3: Immunofluorescence of FABP5 with GFAP in the cortex of sham and ischemia/reperfusion mice.

Author Contributions: Q.G.: investigation and original draft writing; I.K. and T.D.: investigation; Y.I.-M., M.S. and F.H.: methodology; K.F.: supervision, review/editing, project administration and funding. All authors have read and agreed to the published version of the manuscript.

Funding: This research was supported by the Strategic Research Program for Brain Sciences from Japan Agency for Medical Research and Development, AMED [grant numbers JP18dm0107071, JP19dm0107071 and JP20dm0107071] and KAKENHI [grant number 19H03406].

Institutional Review Board Statement: The study was conducted according to the guidelines of the Declaration of Helsinki, and approved by the Institutional Animal Care and Use Committee of the Tohoku University Environmental and Safety Committee, Tohoku University, Japan (Approval ID: 2019PhLM0-021 and 2019PhA-024).

Informed Consent Statement: Not applicable.

Data Availability Statement: The data presented in this study are available on request from the corresponding author.

Acknowledgments: We gratefully thank the Kobayashi Foundation for their financial support.

Conflicts of Interest: The authors declare no conflict of interest.

\section{References}

1. Donnan, G.A.; Fisher, M.; Macleod, M.; Davis, S.M. Stroke. Lancet 2008, 371, 1612-1623. [CrossRef]

2. Durukan, A.; Tatlisumak, T. Acute ischemic stroke: Overview of major experimental rodent models, pathophysiology, and therapy of focal cerebral ischemia. Pharmacol. Biochem. Behav. 2007, 87, 179-197. [CrossRef]

3. Terasaki, Y.; Liu, Y.; Hayakawa, K.; Pham, L.D.; Lo, E.H.; Ji, X.; Arai, K. Mechanisms of Neurovascular Dysfunction in Acute Ischemic Brain. Curr. Med. Chem. 2014, 21, 2035-2042. [CrossRef] [PubMed]

4. Brouns, R.; De Deyn, P.P. The complexity of neurobiological processes in acute ischemic stroke. Clin. Neurol. Neurosurg. 2009, 111, 483-495. [CrossRef]

5. Wu, Q.J.; Tymianski, M. Targeting NMDA receptors in stroke: New hope in neuroprotection. Mol. Brain 2018, 11, 15. [CrossRef]

6. Matsumata, M.; Inada, H.; Osumi, N. Fatty acid binding proteins and the nervous system: Their impact on mental conditions. Neurosci. Res. 2016, 102, 47-55. [CrossRef]

7. Amiri, M.; Yousefnia, S.; Seyed Forootan, F.; Peymani, M.; Ghaedi, K.; Nasr Esfahani, M.H. Diverse roles of fatty acid binding proteins (FABPs) in development and pathogenesis of cancers. Gene 2018, 676, 171-183. [CrossRef] [PubMed]

8. Shimamoto, C.; Ohnishi, T.; Maekawa, M.; Watanabe, A.; Ohba, H.; Arai, R.; Iwayama, Y.; Hisano, Y.; Toyota, T.; Toyoshima, M.; et al. Functional characterization of FABP3, 5 and 7 gene variants identified in schizophrenia and autism spectrum disorder and mouse behavioral studies. Hum. Mol. Genet. 2015, 24, 2409. [CrossRef]

9. Owada, Y. Fatty acid binding protein: Localization and functional significance in the brain. Tohoku J. Exp. Med. 2008, 214, 213-220. [CrossRef] [PubMed] 
10. Liu, R.Z.; Mita, R.; Beaulieu, M.; Gao, Z.; Godbout, R. Fatty acid binding proteins in brain development and disease. Int. J. Dev. Biol. 2010, 54, 1229-1239. [CrossRef] [PubMed]

11. Chiasserini, D.; Biscetti, L.; Eusebi, P.; Salvadori, N.; Frattini, G.; Simoni, S.; De Roeck, N.; Tambasco, N.; Stoops, E.; Vanderstichele, H.; et al. Differential role of CSF fatty acid binding protein 3, alpha-synuclein, and Alzheimer's disease core biomarkers in Lewy body disorders and Alzheimer's dementia. Alzheimers Res. Ther. 2017, 9, 52. [CrossRef] [PubMed]

12. Mollenhauer, B.; Steinacker, P.; Bahn, E.; Bibl, M.; Brechlin, P.; Schlossmacher, M.G.; Locascio, J.J.; Wiltfang, J.; Kretzschmar, H.A.; Poser, S.; et al. Serum heart-type fatty acid-binding protein and cerebrospinal fluid tau: Marker candidates for dementia with Lewy bodies. Neurodegener. Dis. 2007, 4, 366-375. [CrossRef] [PubMed]

13. Jia, W.; Wilar, G.; Kawahata, I.; Cheng, A.; Fukunaga, K. Impaired Acquisition of Nicotine-Induced Conditioned Place Preference in Fatty Acid-Binding Protein 3 Null Mice. Mol. Neurobiol. 2021, 58, 2030-2045. [CrossRef]

14. Jia, W.; Kawahata, I.; Cheng, A.; Fukunaga, K. The Role of CaMKII and ERK Signaling in Addiction. Int. J. Mol. Sci. 2021, 22, 3189. [CrossRef]

15. Shioda, N.; Yabuki, Y.; Kobayashi, Y.; Onozato, M.; Owada, Y.; Fukunaga, K. FABP3 protein promotes alpha-synuclein oligomerization associated with 1-methyl-1,2,3,6-tetrahydropiridine-induced neurotoxicity. J. Biol. Chem. 2014, 289, 18957-18965. [CrossRef]

16. Liao, B.; Geng, L.; Zhang, F.; Shu, L.; Wei, L.; Yeung, P.K.K.; Lam, K.S.L.; Chung, S.K.; Chang, J.; Vanhoutte, P.M.; et al. Adipocyte fatty acid-binding protein exacerbates cerebral ischaemia injury by disrupting the blood-brain barrier. Eur. Heart J. 2020, 41, 3169-3180. [CrossRef]

17. Shi, M.; Huang, R.S.; Guo, F.; Li, L.Z.; Feng, Y.H.; Wei, Z.J.; Zhou, L.; Ma, L.; Fu, P. Pharmacological inhibition of fatty acid-binding protein 4 (FABP4) protects against renal ischemia-reperfusion injury. RSC Adv. 2018, 8, 15207-15214. [CrossRef]

18. Beniyama, Y.; Matsuno, K.; Miyachi, H. Structure-guided design, synthesis and in vitro evaluation of a series of pyrazole-based fatty acid binding protein (FABP) 3 ligands. Bioorg. Med. Chem. Lett. 2013, 23, 1662-1666. [CrossRef] [PubMed]

19. Matsuo, K.; Cheng, A.; Yabuki, Y.; Takahata, I.; Miyachi, H.; Fukunaga, K. Inhibition of MPTP-induced alpha-synuclein oligomerization by fatty acid-binding protein 3 ligand in MPTP-treated mice. Neuropharmacology 2019, 150, 164-174. [CrossRef] [PubMed]

20. Haga, H.; Yamada, R.; Izumi, H.; Shinoda, Y.; Kawahata, I.; Miyachi, H.; Fukunaga, K. Novel fatty acid-binding protein 3 ligand inhibits dopaminergic neuronal death and improves motor and cognitive impairments in Parkinson's disease model mice. Pharmacol. Biochem. Behav. 2020, 191, 172891. [CrossRef]

21. Cheng, A.; Wang, Y.; Shinoda, Y.; Kawahata, I.; Yamamoto, T.; Jia, W.; Yamamoto, H.; Mizobata, T.; Kawata, Y.; Fukunaga, K. Fatty acid-binding protein 7 triggers $\alpha$-synuclein oligomerization in glial cells and oligodendrocytes associated with oxidative stress Acta Pharmacol. Sin. 2021, 0, 1-11.

22. Cheng, A.; Shinoda, Y.; Yamamoto, T.; Miyachi, H.; Fukunaga, K. Development of FABP3 ligands that inhibit arachidonic acid-induced alpha-synuclein oligomerization. Brain Res. 2019, 1707, 190-197. [CrossRef] [PubMed]

23. Shinoda, Y.; Wang, Y.; Yamamoto, T.; Miyachi, H.; Fukunaga, K. Analysis of binding affinity and docking of novel fatty acid-binding protein (FABP) ligands. J. Pharmacol. Sci. 2020, 143, 264-271. [CrossRef] [PubMed]

24. Sun, M.; Izumi, H.; Shinoda, Y.; Fukunaga, K. Neuroprotective effects of protein tyrosine phosphatase 1B inhibitor on cerebral ischemia/reperfusion in mice. Brain Res. 2018, 1694, 1-12. [CrossRef]

25. Sun, M.; Shinoda, Y.; Fukunaga, K. KY-226 Protects Blood-brain Barrier Function Through the Akt/FoxO1 Signaling Pathway in Brain Ischemia. Neuroscience 2019, 399, 89-102. [CrossRef]

26. Yabuki, Y.; Fukunaga, K. Oral administration of glutathione improves memory deficits following transient brain ischemia by reducing brain oxidative stress. Neuroscience 2013, 250, 394-407. [CrossRef]

27. Boneva, N.B.; Mori, Y.; Kaplamadzhiev, D.B.; Kikuchi, H.; Zhu, H.; Kikuchi, M.; Tonchev, A.B.; Yamashima, T. Differential expression of FABP 3, 5, 7 in infantile and adult monkey cerebellum. Neurosci. Res. 2010, 68, 94-102. [CrossRef]

28. Boneva, N.B.; Kaplamadzhiev, D.B.; Sahara, S.; Kikuchi, H.; Pyko, I.V.; Kikuchi, M.; Tonchev, A.B.; Yamashima, T. Expression of fatty acid-binding proteins in adult hippocampal neurogenic niche of postischemic monkeys. Hippocampus 2011, 21, 162-171. [CrossRef]

29. Armstrong, E.H.; Goswami, D.; Griffin, P.R.; Noy, N.; Ortlund, E.A. Structural Basis for Ligand Regulation of the Fatty Acidbinding Protein 5, Peroxisome Proliferator-activated Receptor beta/delta (FABP5-PPAR beta/delta) Signaling Pathway. J. Biol. Chem. 2014, 289, 14941-14954. [CrossRef]

30. Morgan, E.; Kannan-Thulasiraman, P.; Noy, N. Involvement of Fatty Acid Binding Protein 5 and PPAR beta/delta in Prostate Cancer Cell Growth. PPAR Res. 2010, 2010, 234629. [CrossRef] [PubMed]

31. Ikeda-Matsuo, Y.; Ota, A.; Fukada, T.; Uematsu, S.; Akira, S.; Sasaki, Y. Microsomal prostaglandin E synthase-1 is a critical factor of stroke-reperfusion injury. Proc. Natl. Acad. Sci. USA 2006, 103, 11790-11795. [CrossRef]

32. Matsumata, M.; Sakayori, N.; Maekawa, M.; Owada, Y.; Yoshikawa, T.; Osumi, N. The Effects of Fabp7 and Fabp5 on Postnatal Hippocampal Neurogenesis in the Mouse. Stem Cells 2012, 30, 1532-1543. [CrossRef]

33. Sharifi, K.; Ebrahimi, M.; Kagawa, Y.; Islam, A.; Tuerxun, T.; Yasumoto, Y.; Hara, T.; Yamamoto, Y.; Miyazaki, H.; Tokuda, N.; et al. Differential expression and regulatory roles of FABP5 and FABP7 in oligodendrocyte lineage cells. Cell Tissue Res. 2013, 354, 683-695. [CrossRef] 
34. Song, G.X.; Shen, Y.H.; Liu, Y.Q.; Sun, W.; Miao, L.P.; Zhou, L.J.; Liu, H.L.; Yang, R.; Kong, X.Q.; Cao, K.J.; et al. Overexpression of FABP3 promotes apoptosis through inducing mitochondrial impairment in embryonic cancer cells. J. Cell. Biochem. 2012, 113, 3701-3708. [CrossRef]

35. Zhuang, L.; Li, C.; Chen, Q.; Jin, Q.; Wu, L.; Lu, L.; Yan, X.; Chen, K. Fatty acid-binding protein 3 contributes to ischemic heart injury by regulating cardiac myocyte apoptosis and MAPK pathways. Am. J. Physiol. Heart Circ. Physiol. 2019, 316, H971-h984. [CrossRef]

36. Kawahata, I.; Bousset, L.; Melki, R.; Fukunaga, K. Fatty Acid-Binding Protein 3 is Critical for $\alpha$-Synuclein Uptake and MPP+Induced Mitochondrial Dysfunction in Cultured Dopaminergic Neurons. Int. J. Mol. Sci. 2019, 20, 5358. [CrossRef] [PubMed]

37. Ma, D.X.; Zhang, M.M.; Mori, Y.; Yao, C.J.; Larsen, C.P.; Yamashima, T.; Zhou, L.F. Cellular Localization of Epidermal-Type and Brain-Type Fatty Acid-Binding Proteins in Adult Hippocampus and Their Response to Cerebral Ischemia. Hippocampus 2010, 20, 811-819. [CrossRef] [PubMed]

38. Rossi, D.J.; Brady, J.D.; Mohr, C. Astrocyte metabolism and signaling during brain ischemia. Nat. Neurosci. 2007, 10, 1377-1386. [CrossRef] [PubMed]

39. Roy-O'Reilly, M.; McCullough, L.D. Astrocytes fuel the fire of lymphocyte toxicity after stroke. Proc. Natl. Acad. Sci. USA 2017, 114, 425-427. [CrossRef] [PubMed]

40. Ebrahimi, M.; Yamamoto, Y.; Sharifi, K.; Kida, H.; Kagawa, Y.; Yasumoto, Y.; Islam, A.; Miyazaki, H.; Shimamoto, C.; Maekawa, M.; et al. Astrocyte-expressed FABP7 regulates dendritic morphology and excitatory synaptic function of cortical neurons. Glia 2016, 64, 48-62. [CrossRef]

41. Senbokuya, N.; Yoshioka, H.; Yagi, T.; Owada, Y.; Kinouchi, H. Effects of FABP7 on functional recovery after spinal cord injury in adult mice. J. Neurosurg. Spine 2019, 31, 291-297. [CrossRef]

42. Killoy, K.M.; Harlan, B.A.; Pehar, M.; Vargas, M.R. FABP7 upregulation induces a neurotoxic phenotype in astrocytes. Glia 2020, 68, 2693-2704. [CrossRef]

43. Arai, Y.; Funatsu, N.; Numayama-Tsuruta, K.; Nomura, T.; Nakamura, S.; Osumi, N. Role of Fabp7, a downstream gene of Pax6, in the maintenance of neuroepithelial cells during early embryonic development of the rat cortex. J. Neurosci. 2005, 25, 9752-9761. [CrossRef]

44. Tashiro, R.; Sakayori, N.; Matsumata, M.; Owada, Y.; Wakamatsu, Y.; Osumi, N. Fatty acid binding protein (Fabp7) is involved in the maintenance of neural stem/progenitor cells, survival of neurons and maturation of astrocytes. Neurosci. Res. 2011, 71 , E127. [CrossRef]

45. Ruan, L.; Wang, Y.; Chen, S.C.; Zhao, T.; Huang, Q.; Hu, Z.L.; Xia, N.Z.; Liu, J.J.; Chen, W.J.; Zhang, Y.; et al. Metabolite changes in the ipsilateral and contralateral cerebral hemispheres in rats with middle cerebral artery occlusion. Neural Regen. Res. 2017, 12, 931-937. [PubMed]

46. Xu, Z.N.S.; Lee, R.J.; Chu, S.S.; Yao, A.N.; Paun, M.K.; Murphy, S.P.; Mourad, P.D. Evidence of Changes in Brain Tissue Stiffness After Ischemic Stroke Derived From Ultrasound-Based Elastography. J. Ultras Med. 2013, 32, 485-494. [CrossRef] [PubMed]

47. Gangishetti, U.; Christina Howell, J.; Perrin, R.J.; Louneva, N.; Watts, K.D.; Kollhoff, A.; Grossman, M.; Wolk, D.A.; Shaw, L.M.; Morris, J.C.; et al. Non-beta-amyloid/tau cerebrospinal fluid markers inform staging and progression in Alzheimer's disease. Alzheimers Res. Ther. 2018, 10, 98. [CrossRef]

48. Sepe, F.N.; Chiasserini, D.; Parnetti, L. Role of FABP3 as biomarker in Alzheimer's disease and synucleinopathies. Future Neurol. 2018, 13, 199-207. [CrossRef]

49. Teunissen, C.E.; Veerhuis, R.; De Vente, J.; Verhey, F.R.J.; Vreeling, F.; van Boxtel, M.P.J.; Glatz, J.F.C.; Pelsers, M.A.L. Brain-specific fatty acid-binding protein is elevated in serum of patients with dementia-related diseases. Eur. J. Neurol. 2011, 18, 865-871. [CrossRef]

50. Sebastian Monasor, L.; Muller, S.A.; Colombo, A.V.; Tanrioever, G.; Konig, J.; Roth, S.; Liesz, A.; Berghofer, A.; Piechotta, A.; Prestel, M.; et al. Fibrillar Abeta triggers microglial proteome alterations and dysfunction in Alzheimer mouse models. eLife 2020, 9, e54083. [CrossRef] [PubMed]

51. Chitnis, T.; Weiner, H.L. CNS inflammation and neurodegeneration. J. Clin. Investig. 2017, 127, 3577-3587. [CrossRef]

52. Wang, W.Y.; Tan, M.S.; Yu, J.T.; Tan, L. Role of pro-inflammatory cytokines released from microglia in Alzheimer's disease. Ann. Transl. Med. 2015, 3, 136.

53. Zheng, C.; Zhou, X.W.; Wang, J.Z. The dual roles of cytokines in Alzheimer's disease: Update on interleukins, TNF-alpha, TGF-beta and IFN-gamma. Transl. Neurodegener. 2016, 5, 7. [CrossRef]

54. Rao, D.; Perraud, A.L.; Schmitz, C.; Gally, F. Cigarette smoke inhibits LPS-induced FABP5 expression by preventing c-Jun binding to the FABP5 promoter. PLoS ONE 2017, 12, e0178021. [CrossRef]

55. Han, Q.A.; Yeung, S.C.; Ip, M.S.M.; Mak, J.C.W. Effects of intermittent hypoxia on A-/E-FABP expression in human aortic endothelial cells. Int. J. Cardiol. 2010, 145, 396-398. [CrossRef]

56. Kamizato, K.; Sato, S.; Shil, S.K.; Umaru, B.A.; Kagawa, Y.; Yamamoto, Y.; Ogata, M.; Yasumoto, Y.; Okuyama, Y.; Ishii, N.; et al. The role of fatty acid binding protein 7 in spinal cord astrocytes in a mouse model of experimental autoimmune encephalomyelitis. Neuroscience 2019, 409, 120-129. [CrossRef]

57. MacDougall, G.; Anderton, R.S.; Mastaglia, F.L.; Knuckey, N.W.; Meloni, B.P. Proteomic analysis of cortical neuronal cultures treated with poly-arginine peptide-18 (R18) and exposed to glutamic acid excitotoxicity. Mol. Brain 2019, 12. [CrossRef] 
58. Cheng, A.; Kawahata, I.; Fukunaga, K. Fatty Acid Binding Protein 5 Mediates Cell Death by Psychosine Exposure through Mitochondrial Macropores Formation in Oligodendrocytes. Biomedicines 2020, 8, 635. [CrossRef] [PubMed]

59. Rink, C.; Khanna, S. Significance of Brain Tissue Oxygenation and the Arachidonic Acid Cascade in Stroke. Antioxid. Redox Sign. 2011, 14, 1889-1903. [CrossRef] [PubMed]

60. Korbecki, J.; Bobinski, R.; Dutka, M. Self-regulation of the inflammatory response by peroxisome proliferator-activated receptors. Inflamm. Res. 2019, 68, 443-458. [CrossRef] [PubMed]

61. Yu, S.; Levi, L.; Casadesus, G.; Kunos, G.; Noy, N. Fatty acid-binding protein 5 (FABP5) regulates cognitive function both by decreasing anandamide levels and by activating the nuclear receptor peroxisome proliferator-activated receptor beta/delta (PPARbeta/delta) in the brain. J. Biol. Chem. 2014, 289, 12748-12758. [CrossRef] [PubMed]

62. Blitek, A.; Szymanska, M. Peroxisome proliferator-activated receptor beta/delta and gamma agonists differentially affect prostaglandin E2 and cytokine synthesis and nutrient transporter expression in porcine trophoblast cells during implantation. Theriogenology 2020, 152, 36-46. [CrossRef]

63. de Oliveira, A.C.; Candelario-Jalil, E.; Bhatia, H.S.; Lieb, K.; Hull, M.; Fiebich, B.L. Regulation of prostaglandin E2 synthase expression in activated primary rat microglia: Evidence for uncoupled regulation of mPGES-1 and COX-2. Glia 2008, 56, 844-855. [CrossRef]

64. Ikeda-Matsuo, Y. The Role of mPGES-1 in Inflammatory Brain Diseases. Biol. Pharm. Bull. 2017, 40, 557-563. [CrossRef] [PubMed]

65. Bogdan, D.; Falcone, J.; Kanjiya, M.P.; Park, S.H.; Carbonetti, G.; Studholme, K.; Gomez, M.; Lu, Y.; Elmes, M.W.; Smietalo, N.; et al. Fatty acid-binding protein 5 controls microsomal prostaglandin E synthase 1 (mPGES-1) induction during inflammation. $J$. Biol. Chem. 2018, 293, 5295-5306. [CrossRef]

66. Liu, T.; Zhang, L.; Joo, D.; Sun, S.C. NF-kappaB signaling in inflammation. Signal Transduct. Target Ther. 2017, 2, 17023. [CrossRef]

67. Ridder, D.A.; Schwaninger, M. NF-kappaB signaling in cerebral ischemia. Neuroscience 2009, 158, 995-1006. [CrossRef] [PubMed] 